\title{
Submarine Channel Mouth Settings: Processes, Geomorphology, and Deposits
}

\author{
David M. Hodgson ${ }^{1 \star t}$, Jeff Peakall ${ }^{1 \dagger}$ and Katherine L. Maier ${ }^{2 \dagger}$ \\ ${ }^{1}$ School of Earth and Environment, University of Leeds, Leeds, United Kingdom, ${ }^{2}$ National Institute of Water and Atmospheric \\ Research (NIWA), Wellington, Aoteroa New Zealand
}

OPEN ACCESS

Edited by:

Fabiano Gamberi,

National Research Council (CNR), Italy

Reviewed by:

Juraj Janocko,

Technical University of Košice,

Slovakia

Luigi Jovane,

University of São Paulo, Brazil

*Correspondence:

David M. Hodgson

D.Hodgson@leeds.ac.uk

tORCID:

Hodgson D. M.

0000-0003-3711-635X

Peakall J.

0000-0003-3382-4578

Maier K. L.

0000-0003-2908-3340

Specialty section:

This article was submitted to

Sedimentology, Stratigraphy and

Diagenesis,

a section of the journal

Frontiers in Earth Science

Received: 06 October 2021

Accepted: 13 January 2022

Published: 10 February 2022

Citation:

Hodgson DM, Peakall J and Maier KL

(2022) Submarine Channel Mouth Settings: Processes, Geomorphology,

and Deposits.

Front. Earth Sci. 10:790320

doi: 10.3389/feart.2022.790320
Observations from the modern seafloor that suggest turbidity currents tend to erode as they lose channel-levee confinement, rather than decelerating and depositing their sediment load, has driven investigations into sediment gravity flow behaviour at the mouth of submarine channels. Commonly, channel mouth settings coincide with areas of gradient change and play a vital role in the transfer of sediment through deep-water systems. Channel mouth settings are widely referred to as the submarine channel-lobe transition zone (CLTZ) where well-defined channel-levees are separated from well-defined lobes, and are associated with an assemblage of erosional and depositional bedforms (e.g., scours and scour fields, sediment waves, incipient channels). Motivated by recently published datasets, we reviewed modern seafloor studies, which suggest that a wide range of channel mouth configurations exist. These include traditional CLTZs, plunge pools, and distinctive long and flared tracts between channels and lobes, which we recognise with the new term channel mouth expansion zones (CMEZs). In order to understand the morphodynamic differences between types of channel mouth settings, we review insights from physical experiments that have focussed on understanding changes in process behaviour as flows exit channels. We integrate field observations and numerical modelling that offer insight into flow behaviours in channel mouth settings. From this analysis, we propose four types of channel mouth setting: 1) supercritical CMEZs on slopes; 2) plunge pools at steep slope breaks with high incoming supercritical Froude numbers; 3) CLTZs with arrays of hydraulic jumps at slope breaks with incoming supercritical Froude numbers closer to unity; and, 4) subcritical CLTZs associated with slope breaks and/or flow expansion. Identification of the stratigraphic record of channel mouth settings is complicated by the propagation, and avulsion, of channels. Nonetheless, recent studies from ancient outcrop and subsurface systems have highlighted the dynamic evolution of interpreted CLTZs, which range from composite erosion surfaces, to tens of metres thick stratigraphic records. We propose that some examples be reconsidered as exhumed CMEZs.

Keywords: submarine channel, lobe, channel-lobe transition zone, channel mouth expansion zone, supercritical flow, bedform migration 


\section{INTRODUCTION}

Turbidity currents are sensitive to changes in orientation and gradient in seafloor topography, and to the nature (height and form) of lateral confinement. At submarine sites of abrupt changes in lateral confinement, such as at the mouth of submarine channels, or gradient changes, such as at the baseof-slope, flows undergo rapid changes in character (i.e., velocity, stratification, thickness) (e.g., Mutti and Normark, 1987; Mutti and Normark, 1991). These changes profoundly influence patterns of erosion and deposition, and therefore flowtopography interactions are dynamic in time and space.

Traditionally, submarine siliciclastic sedimentary systems are subdivided into 1) high gradient slope or ramp settings, dominated by erosion and sediment bypass processes, and 2) low gradient basin floor or step settings, dominated by depositional processes (e.g., Posamentier and Kolla, 2003). Commonly, the change from higher to lower gradients at the base of slope coincides with channel mouth settings. Channels in many examples appear separated from lobe deposits by transitional areas, widely referred to as channel-lobe transition zones (CLTZs; Mutti and Normark, 1987; Mutti and Normark, 1991; Wynn et al., 2002a). Mutti and Normark (1987) defined a CLTZ as "the region that, within any turbidite system, separates well-defined channels or channel-fill from well-defined lobes or lobe facies." However, on review of the literature, including recent studies of modern seafloor systems, we propose that CLTZs are one type of a broad spectrum of configurations at channel mouth settings, and consider the likely dominant sedimentary processes and stratigraphic expression of these types.

Typically, channel mouth settings are dominated by sediment bypass (Stevenson et al., 2015; Brooks et al., 2018), and rapid flow deceleration and expansion. These processes have in turn been postulated to be associated with the occurrence of hydraulic jumps, where flows transform from supercritical to subcritical states (e.g., Komar, 1971; García and Parker, 1989; Normark and Piper, 1991; Alexander et al., 2001; Wynn et al., 2002a; Kostic and Parker, 2006; Ito, 2008; Macdonald et al., 2011a; Shaw et al., 2013; Sumner et al., 2013; Hofstra et al., 2015; Dorrell et al., 2016). Thus, it can be proposed, based on this existing literature, that there will be a relative abundance of supercritical and transcritical bedforms, including antidunes, cyclic steps, and scours, associated with channel mouth settings. Observations from modern-day channel mouth settings indicate that they are characterized by a distinctive assemblage of erosional bedforms, such as isolated or coalesced scours, and depositional bedforms, such as lags and sediment waves (e.g., Normark et al., 1979; Kenyon et al., 1995; Kenyon and Millington, 1995; Wynn et al., 2002b; Fildani and Normark, 2004; Maier et al., 2018; Droz et al., 2020; Maier et al., 2020).

There is a growing literature on CLTZs interpreted from ancient outcrops (see compilation by Navarro and Arnott, 2020), with recognition criteria proposed to support links between sedimentary processes and deposits (e.g., Bravo and Robles, 1995; Ito, 2008; Pyles et al., 2014; Hofstra et al., 2015; Pemberton et al., 2016; Postma et al., 2016; Brooks et al., 2018; Hofstra et al., 2018; Postma et al., 2021). Preserved stratigraphic

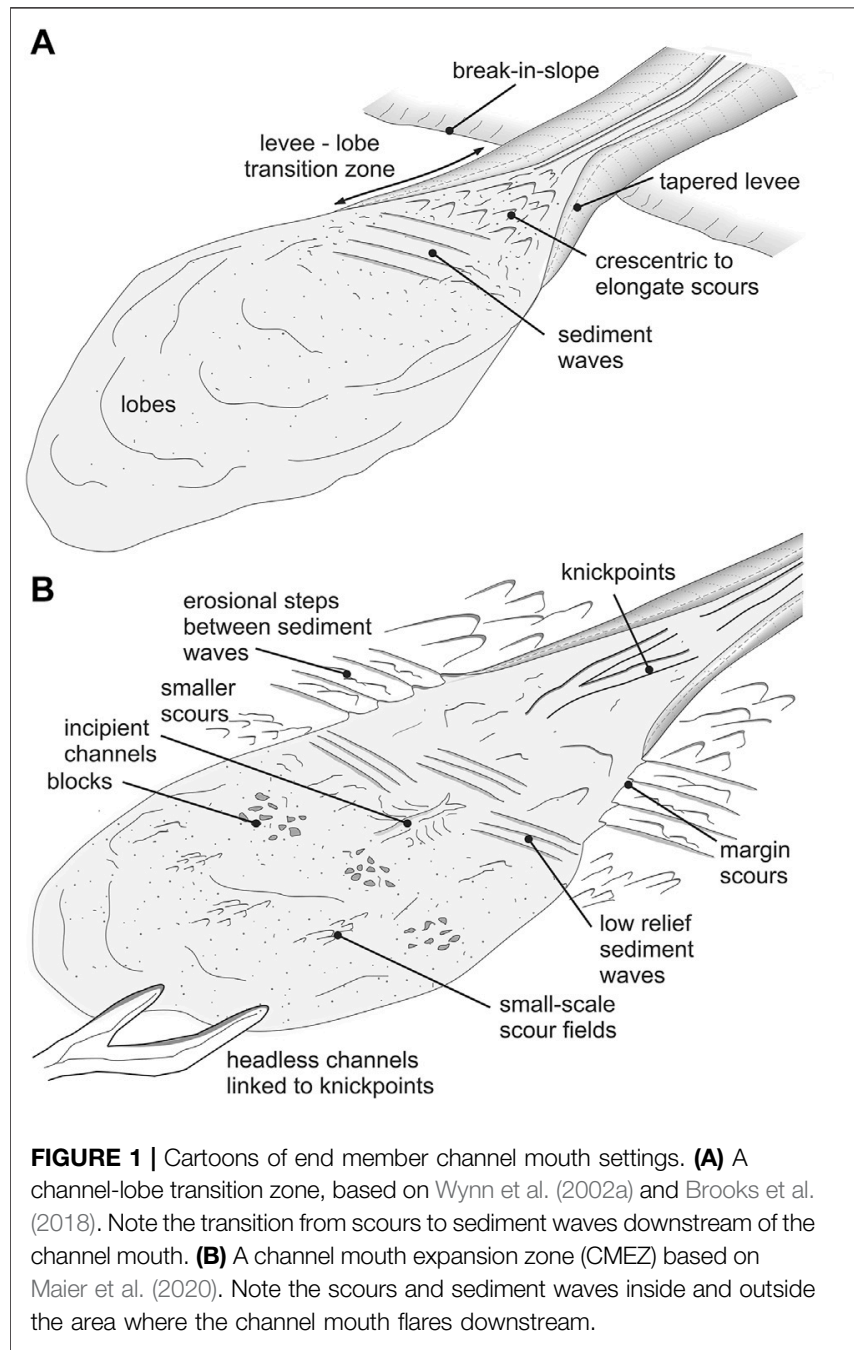

successions of interpreted CLTZs range from thick successions of aggradational beds in close association with scour-fill features (e.g., Pemberton et al., 2016; Brooks et al., 2018; Mansor and Amir Hassan, 2021; Brooks et al., 2022) to single surfaces that separate lobes from overlying channel-levee systems (e.g., Gardner et al., 2003; Hodgson et al., 2016). The wide range of expressions and dimensions (Navarro and Arnott, 2020) point to a number of parameters and configurations that control the transfer, and preservation, of channel mouth settings into the rock record.

The focus of studies on submarine channel mouth settings has shifted, evolving from largely petroleum reservoir motivations to include a renewed focus on deep-sea sediment transport processes, implications for seafloor infrastructure hazards, organic carbon flux and burial, benthic ecology, and pollutants (e.g., Kane and Clare, 2019). We aim to summarise the key observations of channel mouth settings from experimental studies, modern systems, and ancient systems to consider the feedbacks between (dynamic) seafloor topography, channel morphology, substrate, and flow rheology on changes in flow behaviour and deposits. Our objectives are to: 1) generate new 
conceptual geomorphological models of channel mouth settings across a range of different geographic locations; 2) assess typical sedimentary processes associated with each of these channel mouth settings; and 3) identify examples of these channel mouth settings in the geological record, and discuss examples that may require reinterpretation.

\section{NOMENCLATURE AND DEFINITIONS}

Relative to channel-levee systems and depositional lobes, the geomorphology, process sedimentology and stratigraphy of channel mouth settings are less widely documented. However, based on observations of modern systems, a more diverse suite of channel mouths settings exist that differ in scale and geomorphology from CLTZ examples.

Many parameters need to be considered when documenting submarine channel mouth settings. Physiographically, these settings commonly coincide with transitions from a slope to basin floor setting (or from a ramp to a step on a stepped slope), which can range from an abrupt gradient change (i.e., a break of slope up to several degrees) to a subtle transition over a relatively smooth seafloor profile. Similarly, submarine channel mouths can range from an abrupt termination to a broad flaring geometry, and be confined by incision or levee construction, or a combination. Furthermore, the morphodynamic configuration is likely to change in space and time through flow-deposit interactions and feedbacks.

To start, we consider a range of potential channel mouth configurations using ancient and recent studies (Figure 1): 1) broad areas of complex erosional and depositional morphologies (channel-lobe transition zones (CLTZs); e.g., Wynn et al., 2002a), and 2) channel mouth expansion zones (CMEZs), a new term we introduce to highlight distinctive examples identified in recent high-resolution seafloor surveys (e.g., Maier et al., 2020). Furthermore, we consider plunge pools (e.g., Lee et al., 2002) as part of the spectrum of channel mouth settings.

CLTZs tend to be associated with abrupt breaks in slope (Figure 1A), with a concomitant rapid change from flows confined by channels to unconfined flows. Classically, this tract is characterised by lags and scours immediately downdip of the channel with a range of forms and degree of coalescence, passing into areas dominated by sediment waves, before lobes. Reported dimensions of CLTZs range from a few $\mathrm{kms}$ to $10 \mathrm{~s}$ of $\mathrm{km}$ in widths and lengths (e.g., Kenyon et al., 1995; Kenyon and Millington, 1995; Morris et al., 1998; Wynn et al., 2002a; Navarro and Arnott, 2020). However, this configuration can be dynamic, and can expand, contract, and migrate (Brooks et al., 2018).

In contrast, CMEZs are characterised by long and broad areas of flaring of the channel and are identified where gradient changes are subtle to absent, but are present on a slope (Maier et al., 2018, Maier et al., 2020; Fildani et al., 2021). Criteria to define where the channel component ends and the lobe component starts, such as aspect ratio or degree of incision, have not been established. Furthermore, examples have identified a complex array of scour forms, incipient channel forms, and sediment waves adjacent to

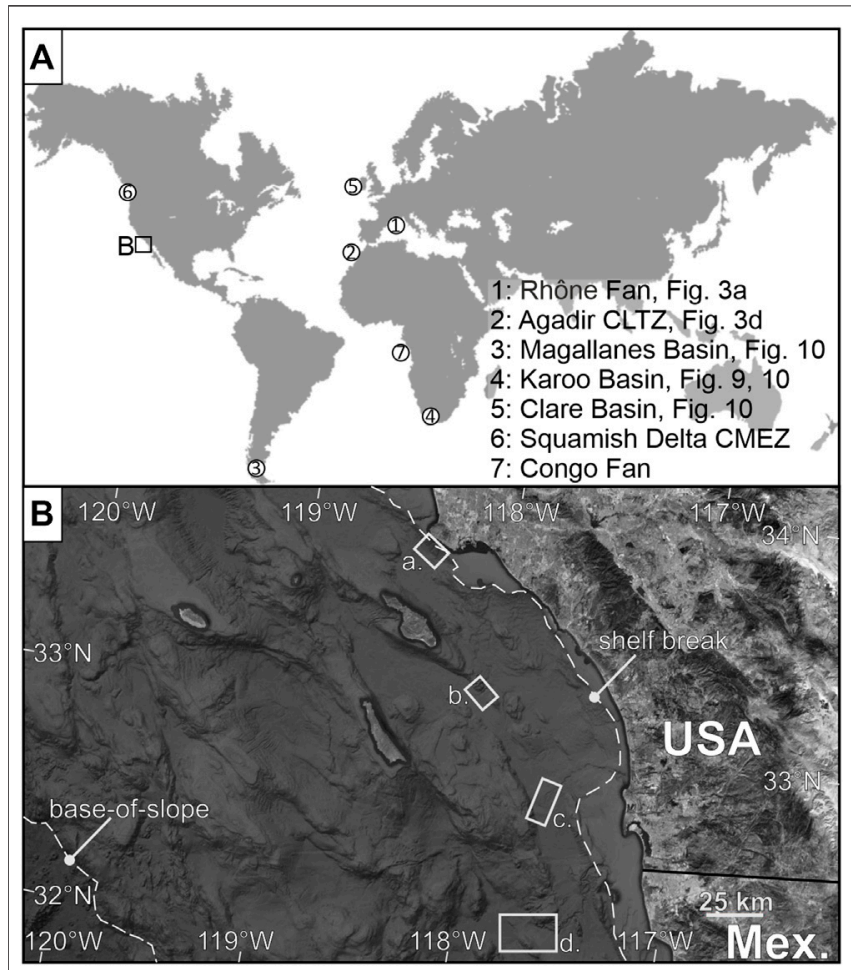

FIGURE 2 | (A) and (B) Location maps of the channel mouth settings reported here. (B) Onshore and offshore map from GoogleEarth to highlight the locations of study areas offshore Southern California; (a) plunge pool sites (Lee et al., 2002; Figure 5); (b) the San Gabriel channel and fan (Maier et al., 2018; Figure 4); (c) the La Jolla Fan (Maier et al., 2020; Figure 4); and, (d) the Navy Fan (Carvajal et al., 2017; Figure 4). Note that all the sites are located on a topographically complex continental slope. Mex. = Mexico.

the area of channel flaring (Figure 1B; e.g., Carvajal et al., 2017; Maier et al., 2020).

We document plunge pools, CLTZs and CMEZs identified in modern systems to summarise previous work on the transition from well-defined channels to well-defined lobes. Subsequently, we consider flow process understanding derived from physical experiments, numerical simulations and real-world flow measurements, and then the stratigraphic expressions of exhumed systems interpreted to record channel mouth settings. This approach permits an alternative classification of channel mouth configurations to be proposed, which can form the basis for future investigations using modern, ancient, and experimental datasets.

\section{COMPARISON OF MODERN SEAFLOOR SETTINGS}

Seafloor studies have been key components of advancing understanding of submarine channel mouth settings for many decades, largely because they allow detailed plan-view perspectives that provide snapshots of time-transgressive morphology (e.g., Mutti and Normark, 1987; Wynn et al., 

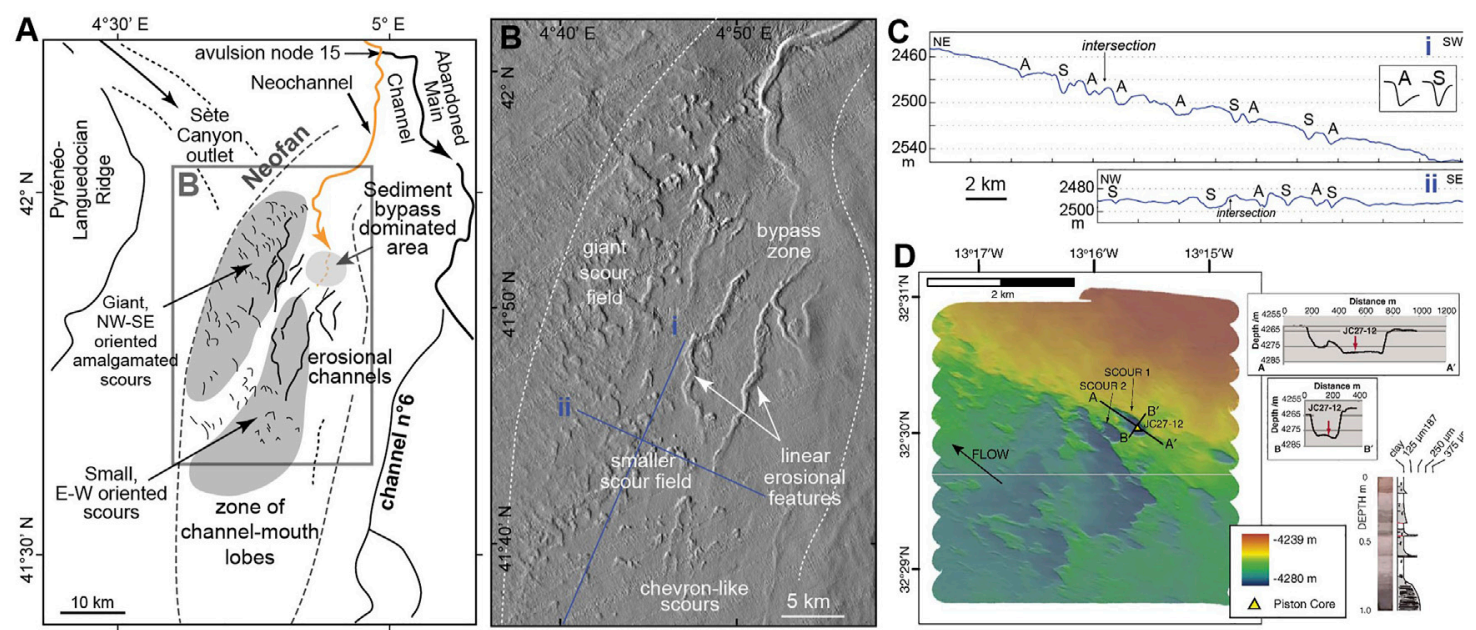

FIGURE 3 | Erosional CLTZ seafloor features. Schematic interpretive map (A), shaded multibeam bathymetry (B), and seafloor relief profiles (C) of the Rhône neofan CLTZ (modified from Droz et al., 2020, courtesy of L. Droz). (C) Seafloor profiles from the Rhône neofan CLTZ (modified from Droz et al., 2020, courtesy of L. Droz). Scours are designated as asymmetrical (A) and symmetrical (S). (D) Autosub6000 high-resolution bathymetry, seafloor profiles, and piston core from long-lived mega-scours from the Agadir CLTZ (modified from Macdonald et al., 2011a).

2002a; Macdonald et al., 2011a; Macdonald et al., 2011b and references therein). Wynn et al. (2002a) summarised significant advances in morphology and processes at submarine channel mouths that were gained largely from deep-towed side-scan sonar, revealing seafloor CLTZs commonly associated with breaks in slope, scours, amalgamated erosional features, and sediment waves (Figure 1A). Subsequent advances in multibeam echosounder datasets, autonomous underwater vehicles, and remotely operated vehicles have produced seafloor datasets with increasing detail and have allowed better definition of channel and lobe environments (c.f. Mutti and Normark, 1987). Numerous studies since Mutti and Normark (1987)'s definition of a CLTZ and Wynn et al. (2002a)'s compilation have presented detailed studies of channel mouth settings on the modern seafloor. Here we discuss these advances by highlighting five examples with somewhat different character-mixed sand-mud Rhône Fan, sandy La Jolla Fan, the Squamish Delta, the mud-rich Congo Fan, and the base-of-slope plunge pools offshore North America (Figure 2).

\section{CLTZ in the Mixed Sand-Mud Rhône Fan, Western Mediterranean Sea}

The Rhône Fan, Gulf of Lions, western Mediterranean Sea (Figure 2), is a mixed sand and mud depositional system fed by the Petit-Rhône Canyon that was connected to the Rhône River during the Last Glacial Maximum (Droz et al., 2020). Imaging and interpretation of Rhône Fan CLTZs have been updated recently, following earlier recognition of erosional CLTZ features by Kenyon et al. (1995) and Wynn et al. (2002a). Multibeam bathymetry, subsurface profiles and piston cores collected across the youngest channel-fan in the Rhône system (i.e., neofan) by Bonnel et al. (2005) showed coalesced giant scours ( $4 \mathrm{~km}$ long, $1 \mathrm{~km}$ wide, $20 \mathrm{~m}$ deep) in a scour field downslope and offset from the neofan channel mouth. Core samples from the distal neofan channel levees showed finegrained (silt and fine sand) turbidites punctuating hemipelagic oozes (Bonnel et al., 2005).

More extensive multibeam bathymetry coverage ( $50 \mathrm{~m}$ grid) and analysis presented in Droz et al. (2020) revealed the neofan CLTZ as a region dominated by erosion and bypass of turbidity currents that separates the youngest channel and lobe. The CLTZ includes a 5-km-long smooth area out of the channel mouth, interpreted as a sediment bypass zone, and much larger adjacent and down-slope areas dominated by small scours (5-10 $\mathrm{m}$ deep and $<500 \mathrm{~m}$ wide), coalesced giant scours (10-30 $\mathrm{m}$ deep, 1-2 km wide, 1-5 km long), and erosional headless channels (Droz et al., 2020) (Figures 3A-C). These headless linear to sinuous erosional channels, and scours merging into megaflutes at the CLTZ, were determined to be a driver for channel inception (e.g., Gamberi and Marani, 2011; Fildani et al., 2013), development of channel confinement, and fan channel extension (Droz et al., 2020). This may contrast with the longlived (>0.2 Myr) giant scours in the Agadir CLTZ (Figure 3D; see Macdonald et al., 2011a). Droz et al. (2020) found that, although the shape of channel-mouth lobes is controlled by the available space between channel-levee deposits and mounds created by subsurface salt diapirs, CLTZ occurrence is determined by the gradient along the channel up-slope from the channel mouth slope break, with more detachment associated with higher gradients. For example, differences in upslope gradient of only $0.13^{\circ}$ were observed to change the amount of detachment.

\section{CMEZ in the Sand-Rich La Jolla Fan, Offshore Southern California}

The Southern California and Mexican Borderlands, offshore western North America, host many small, sand-rich canyon- 


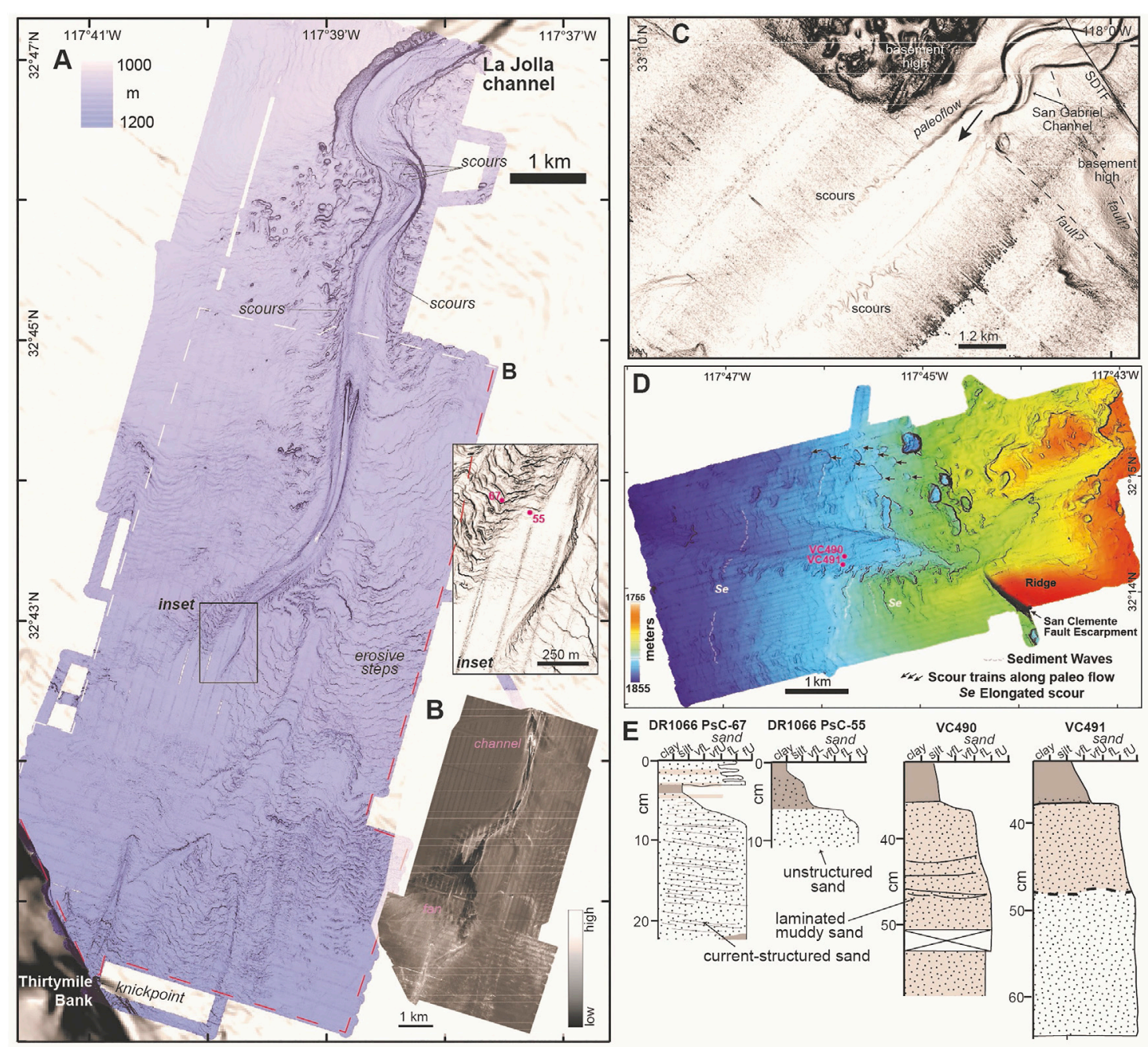

FIGURE 4 | Channel mouth expansion zone (CMEZ) examples from offshore Southern California. La Jolla Fan high-resolution (1-m grid) multibeam bathymetry (A) and backscatter (B) (modified from Maier et al., 2020). Regional bathymetry from Dartnell et al. (2015). (C) San Gabriel channel and fan, Catalina Basin (modified from Maier et al., 2018). (D) Navy Fan (modified from Carvajal et al., 2017). (E) Sediment cores from the Navy Fan (right; modified from Carvajal et al., 2017) and La Jolla Fan (left; from Maier et al., 2020); see inset and part (D), respectively for core locations.

fan systems that route sediment across relatively steep slopes (e.g., $>0.5^{\circ}$; Covault et al., 2017; Figure 2). In many of these systems, turbidity current deposition has continued through Holocene sea-level rise via canyon incision across narrow continental shelves in this tectonically active region (e.g., Normark et al., 2009). A notable example of this is the longshore drift fed La Jolla canyon-fan (Covault et al., 2007). Here, we highlight La Jolla because 1) it has been historically important in development of canyon-fan scientific knowledge (e.g., Shepard, 1951; Normark, 1970; Piper, 1970), 2) recent examination of La Jolla channel mouth applied extensive high-resolution (1-m grid) seafloor data coverage (Maier et al., 2020) (Figures 4A,B), and 3) well-imaged features in La Jolla have similarities in the region (e.g., Carvajal et al., 2017; Maier et al., 2018) (Figures 4C,D).

High-resolution seafloor and shallow subsurface data in La Jolla Canyon (Paull et al., 2013) and fan (Maier et al., 2020) revealed the most recently active part of the La Jolla depositional system forms a CMEZ (Figures 4A,B). As the channel connected to La Jolla Canyon enters the CMEZ (shift from $0.4^{\circ}$ to $0.2^{\circ}$ ), it widens (from $150 \mathrm{~m}$ to $350 \mathrm{~m}$ ), shallows (from $37 \mathrm{~m}$ to $3-5 \mathrm{~m}$ relief), and channel margins become dissected by wide (50-100 m) scours oriented perpendicular to the channel (Figure 4A). This widening channel morphology appears to be common in the region (Navy Fan in Carvajal et al., 2017; San Gabriel Fan in Maier et al., 2018) (Figure 2, Figures 4C,D). These share similarities with other global canyon-fan systems (e.g., Al Batha Fan in Bourget et al., 2010; Hatteras Canyon in Gardner et al., 2016; the Hudson and Wilmington Channels in Deptuck and Sylvester, 2018), and all fit with a CMEZ interpretation. In La Jolla, the wide channel-margin scours continue into laterally extensive $(\mathrm{kms})$ erosive steps carved into sandy lobe deposits. These bedforms are interpreted as cyclic steps, erosional upper flow regime bedforms formed from flows not contained by the low-relief 
distal channel (Fildani et al., 2021). Within the steps, scours have aligned, and are imaged at various stages of coalescing into incipient channels that are offset from, and not yet connected to, the La Jolla channel. Headless channels are also found in Monterey Fan (Normark, 1985; Klaucke et al., 2004) and San Gabriel Fan (Maier et al., 2018). Similarly, Bourget et al. (2010) interpreted the Al Batha Fan CMEZ to be dominated by scours that merged downslope into small channels. The combined La Jolla seafloor morphology, backscatter and sidescan sonar maps (Maier et al., 2020) appear similar to a braided morphology described by Ó Cofaigh et al. (2006) where the high-latitude Lofoten Channel loses confinement. Maier et al. (2020) also identified a most recent sandy lobe deposit extending as a radial fan $(3 \times 2.8 \mathrm{~km})$ from the wide and shallow channel mouth across relatively flat seafloor $\left(0.2^{\circ}\right)$ with less erosional relief, but where large (up to $0.25 \mathrm{~m}$ height, 3-5 m width/ depth) blocks are imaged. Most of the La Jolla CMEZ is dominated by erosional morphologies, with limited observation of sediment waves, which are present in the Navy Fan example to the south (Carvajal et al., 2017; Maier et al., 2020).

\section{CMEZ in the Squamish Delta, British Columbia, Canada}

The pro-delta slope of the Squamish Delta, in Howe Sound (Figure 2), is characterised by channels that widen downstream (Vendettuoli et al., 2019). The southern channel shows a marked bypass surface, prior to lobe deposition, and a reincised channel immediately updip of the bypass zone (Vendettuoli et al., 2019). The channel, bypass area, and lobe, in this system are characterised by upstream-migrating bedforms evolving during supercritical flows (Vendettuoli et al., 2019). This southern channel has been described as a CLTZ, but the flaring channel geometry, presence on a steep slope, and the lack of a significant slope break at the channel mouth, all fit with an interpretation as a CMEZ. Recent measurements of turbidity currents across kilometres from river delta to submarine lobes in the Squamish system and other fjords of British Columbia, Canada (Figure 2), provide key insights into the links between morphology, flow characteristics, frequency, and deposits (e.g., Hughes Clarke et al., 2012; Clare et al., 2016; Hughes Clarke, 2016; Hizzett et al., 2018; Vendettuoli et al., 2019; Heijnen et al., 2020). Vendettuoli et al. (2019) used repeat multibeam bathymetry to monitor $>100$ flows during 4 months in Squamish Delta, and less than half reached the CMEZ. As interpreted in the La Jolla Fan (Maier et al., 2020) and Rhône Fan (Droz et al., 2020), bathymetric monitoring of turbidity currents in Squamish Delta shows scours within the bedforms elongating and merging into proto-channels, progressively capturing more of flows with time (Hughes Clarke and Fedele, 2019). Vendettuoli et al. (2019) found the CMEZ to be a zone dominated by erosion in which deposits were removed by infrequent powerful flows. Erosion was largely via knickpoint retrogression, creating erosional surfaces visible as possible foresets along the CMEZ (Vendettuoli et al., 2019).
Knickpoints generated in the CMEZ propagated upstream and played a key role in channel evolution (Heijnen et al., 2020); thus, CMEZ dynamics potentially impact channel evolution and morphology along much of the system.

\section{Linked Channel and Lobe in the Mud-Rich Congo Fan, Offshore West Africa}

Large, mud-rich, river-fed submarine fans along passive margins, such as the Congo Fan (e.g., Babonneau et al., 2002; Dennielou et al., 2017), display somewhat different character at channel mouths. Wynn et al. (2002a) considered the Congo Fan to be a system without a CLTZ, and likewise, publications that are more recent have interpreted channels with attached lobes (e.g., Picot et al., 2016; Dennielou et al., 2017). Congo channel-mouth lobes have erosional bases and appear to build from connected lobe channels ( $\sim 15$ m relief) by bifurcation of the feeder channel (Picot et al., 2016), which Dennielou et al. (2017) interpret as facilitated by sliding at lobe sides and broad spill-over of poorly confined turbidity currents in the distal channels. Within this attached channel-lobe setting, recent bathymetric compilations across the Congo Fan, including 1-m-resolution bathymetry across parts of the active channel-lobe, reveal some features similar to the La Jolla and Rhône fans. These include wide, flat and shallow channels (up to $5 \mathrm{~km}$ wide, $\sim 0.14^{\circ}, 8 \mathrm{~m}$ deep), knickpoints, sediment waves, blocks (5-10 $\mathrm{m}$ wide, $3 \mathrm{~m}$ high) with adjacent scours, and other signs of erosion or mass failure (Dennielou et al., 2017).

\section{Plunge Pools at the Base of Slope, Offshore North America}

In contrast to the examples above, the base of gullied continental slopes outside of major fan systems with large $\left(>4^{\circ}\right)$ breaks in slope are characterised by plunge pool depressions (Lee et al., 2002). We highlight here examples offshore North America, where Lee et al. (2002) used multibeam bathymetry to document base-of-slope plunge pools on average $400 \mathrm{~m}$ diameter and $21 \mathrm{~m}$ depth, but up to $1,100 \mathrm{~m}$ wide and $75 \mathrm{~m}$ depth (Figure 2, Figure 5). These plunge pools occurred on the active tectonic margin of California and the passive margin of New Jersey. They were identified exclusively in settings with breaks in slope $>4.2^{\circ}$, and most commonly where breaks in slope exceed $9.8^{\circ}$ (Lee et al., 2002). Additional coverage of continental margins with multibeam bathymetry along Cascadia (Nelson et al., 2000; Patton et al., 2013) and Gulf of Alaska (Mayer and Gardner, 2016) margins also revealed base-of-slope plunge pools (up to $2.3 \mathrm{~km}$ diameter and $250 \mathrm{~m}$ depth) at large breaks in gradient. Similarly, carbonate depositional systems of the Bahamas contain plunge pools aligned at the base of steep $\left(2-20^{\circ}\right)$ escarpments, where they are separated by small ridges and followed down-slope by sediment wave fields (Schnyder et al., 2018).

Plunge pool depressions have been interpreted along siliciclastic submarine canyons associated with steep knickpoints within canyon thalwegs (e.g., Gamberi and Marani, 2007; Paull et al., 2011; Harris et al., 2014), and 


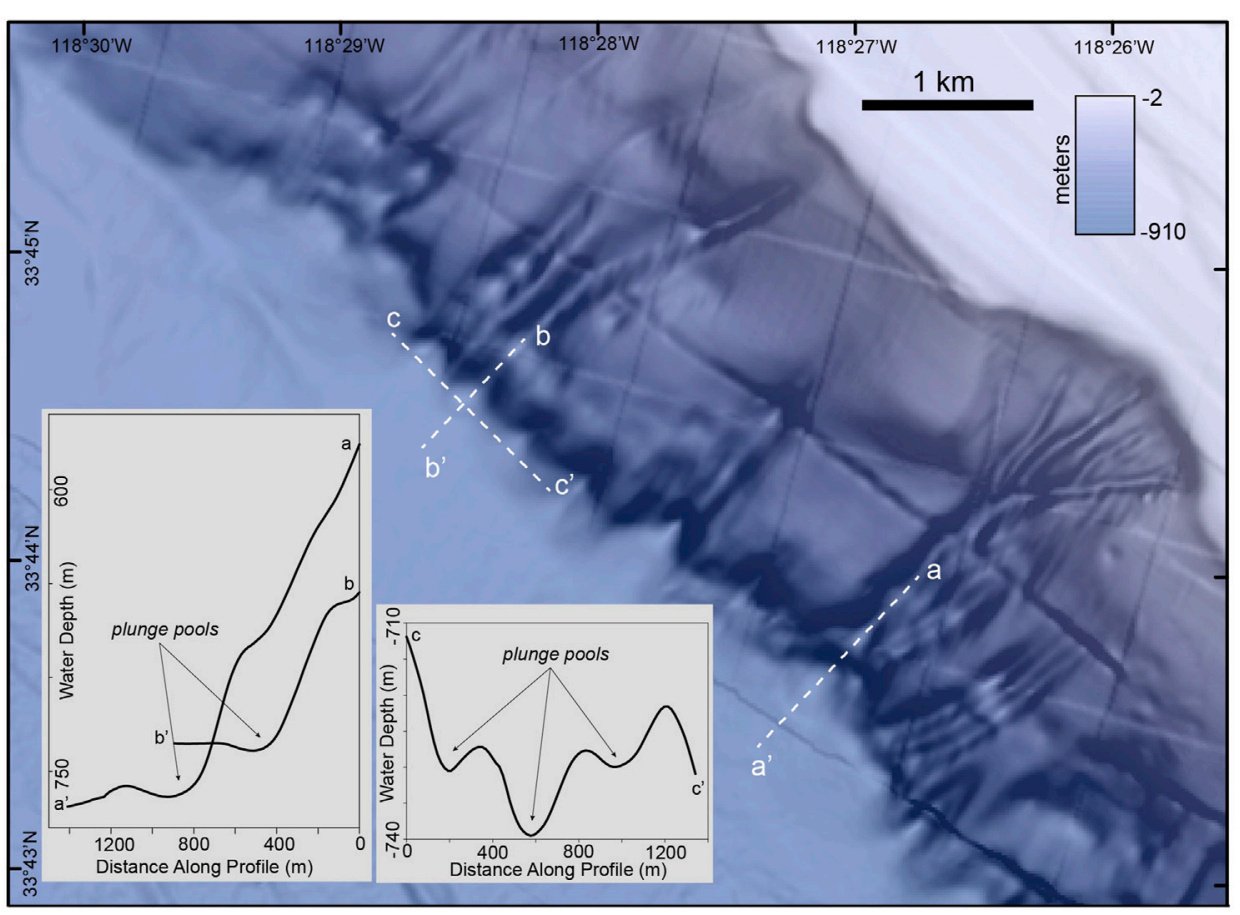

FIGURE 5 | Plunge pools at the base of slope, offshore Southern California. Map shown is colour-contoured multibeam bathymetry draped over slope-shaded bathymetry. Bathymetric grid (16 m) from Gardner and Dartnell (2002) and plunge pool interpretations after Lee et al. (2002).

plunge pools along wide carbonate canyons occur downstream from chutes (knickpoints with hundreds of metres of relief, c. f., Mulder et al., 2019; Recouvreur et al., 2021). In the central equatorial Pacific, plunge pools $\sim 100$-m-deep were recently documented where channels cross steep $\left(5-11^{\circ}\right)$ gradients and transition into sediment wave fields (Gardner et al., 2020). Plunge pools in channel and base of slope settings have been interpreted to form from down-slope sediment density flows that scour on impact at the base of slope, or they scour and deposit at a hydraulic jump caused by the break in slope, or both (Lee et al., 2002), although carbonate examples may also be influenced by erodibility of sediment and changes in underlying rock lithology (e.g., Schnyder et al., 2018; Mulder et al., 2019).

\section{INSIGHTS FROM PHYSICAL EXPERIMENTS, NUMERICAL SIMULATIONS AND REAL-WORLD FLOW MEASUREMENTS}

\section{Process Studies of Channel Mouth Settings}

Process studies on channel mouth settings have been predominantly undertaken using physical modelling (e.g., Pohl et al., 2019; Spychala et al., 2020; Lang et al., 2021). In addition, there is a broader body of experimental work on density flows crossing slope breaks (e.g., García and Parker, 1989; García, 1993; Gray et al., 2005; Gray et al., 2006; Pohl et al., 2020), which can provide insights into channel mouth processes. No flow measurements have been reported in natural deep-sea channel mouth settings. However, the dynamics of gravity flows undergoing hydraulic jumps over scours within a subaqueous channel system has been examined (Sumner et al., 2013; Dorrell et al., 2016). Alongside these experiments and field measurements, we highlight numerical simulations and physical experiments where flows change from supercritical to subcritical in the absence of a hydraulic jump (García, 1993; Kostic and Parker, 2006; Kostic and Parker, 2007; Salinas et al., 2020), and discuss the potential implications for channel mouth settings.

\section{Supercritical Versus Subcritical CLTZs?}

It has been argued for CLTZs that these differ as a function of the Froude (Fr) number, with supercritical CLTZs varying from subcritical examples (Postma et al., 2016). This view is based in part on supercritical fan experiments on steep continuous slopes (Hamilton et al., 2015; Hamilton et al., 2017). Deposition at the channel mouth forms a mouth bar, leading to development of a hydraulic jump which retrogrades with associated upstream retreat of the channel-lobe transition zone (Hamilton et al., 2015; Hamilton et al., 2017). Such processes are characterised by erosive channels, and bedload-dominated systems, on steep slopes (Hamilton et al., 2017). Postma et al. (2016) contrast such supercritical systems with subcritical systems dominated by levee construction, and thus suspension-dominated load, where the channel-lobe transition is controlled by a slope break (Fernandez et al., 2014). These experiments examined 


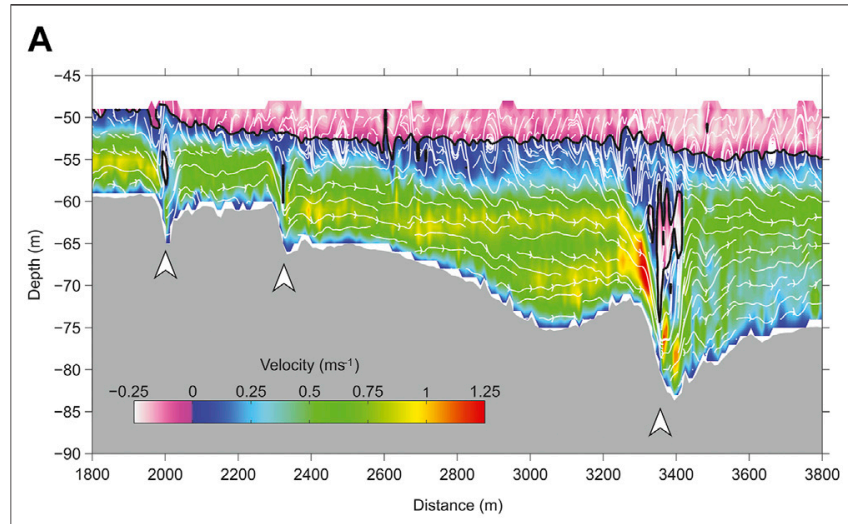

B

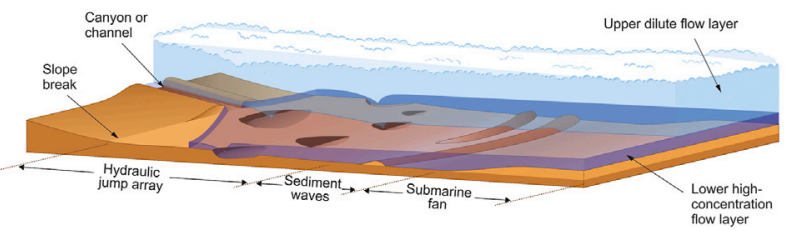

FIGURE 6 | (A) Downstream flow velocity distributions over a series of scours and their associated subaqueous hydraulic jumps, in a channelized saline-driven flow in the Black Sea. The positions of the hydraulic jumps are marked by white arrows. (B) Schematic channel-lobe transition zone showing an array of subaqueous hydraulic jumps occurring in the lowermost high momentum part of the flow. The position and proportion of active hydraulic jumps likely varies between and during flows. Modified from Dorrell et al. (2016).

entire submarine fans, and as such are not primarily focused on the mechanics at the channel mouth. Here we focus on the mechanics of flow and sedimentary processes within channel mouth settings, whilst considering flow criticality and breaks of slope. A number of different processes have been proposed to dominate channel mouth settings, and we consider each in turn, prior to introducing some possible additional mechanisms.

\section{Hydraulic Jumps and Hydraulic Jump Arrays at Breaks in Slope}

Experimental studies of hydraulic jumps at two-dimensional slope breaks, in net depositional fine-grained turbidity currents, show dramatic thickening and deceleration of the flow, leading to a rapid drop in bed shear stresses immediately downstream of the jump (García and Parker, 1989; García, 1993). Therefore, bedload deposition is predicted to occur rapidly downstream of the jump, but for fine-grained suspended sediment deposition may take place over distances in excess of 1,000 times the jump height (García and Parker, 1989; García, 1993). Measurements of natural subaqueous hydraulic jumps has only been undertaken in saline flows in a channel in the Black Sea, where the jumps were associated with seafloor scours (Figure 6A; Sumner et al., 2013; Dorrell et al., 2016). These flows had much lower incoming Froude numbers than the aforementioned experiments, and showed repeating hydraulic jumps, with flows becoming critical again over $\sim 10$ scour lengths. Flow measurements showed large vertical velocities, enhanced mixing, and in contrast to the experiments, showed maintenance of near-bed shear stresses downstream of the jumps (Sumner et al., 2013; Dorrell et al., 2016). Thus, suspended sediment will be mixed and moved upwards within the flow immediately downstream of the jump, and erosion rates and flow capacity maintained, enabling bypass zones to develop. In the Black Sea, subaqueous hydraulic jumps only affected the lower part of the flow, with bypass of flow above the jump, raising the possibility that in larger flows hydraulic jumps may only affect a comparatively small fraction of the stratified flow, associated with the bulk of the momentum (Dorrell et al., 2016). These results suggest that for steep slopes with high incoming Froude numbers, just a single hydraulic jump will occur, which would fit with plunge pool formation (e.g., Lee et al., 2002; Gardner et al., 2020). In contrast, for incoming supercritical flows with Froude numbers close to unity at a slope break, then an array of hydraulic jumps will form, each associated with a scour (Figure 6B). For a given set of flow conditions, only a subset of the scours will likely have active hydraulic jumps (Figure 6B; cf. Macdonald et al., 2011a). Dorrell et al. (2016) further suggested that in the case of mud-rich channelized systems, spatial and temporal variation in the position of these stratified, subaqueous hydraulic jumps may account for the lack of an obvious supercritical to subcritical transition, and the associated absence of CLTZs, in some of these systems.

\section{Flows Across Continuous Slopes Without Hydraulic Jumps}

The influence of loss of flow confinement has been examined by comparing an instantaneous transition from a leveed channel to an unconfined setting, in the absence of a slope break, to a continuous channel over the same area (Pohl et al., 2019). These experiments showed that erosion was considerably larger in the unconfined case over a distance of $\sim 2.5$ channel widths, than at the equivalent point in the continuous channel (Pohl et al., 2019). A 'flow relaxation' mechanism is proposed where the pressure gradient expands the flow laterally, leading to the flow moving closer to the bed, lowering the height of the velocity maximum, and thus increasing basal shear stresses and enhancing erosion (Figure 7). Scours are proposed to be triggered by random irregularities on the seafloor. The experiments used the Shields scaling approach (De Leeuw et al., 2016) to balance the applied fluid shear stress and the gravity force acting on particles, thus enabling particles to remain in suspension. Sediments consisted of silt and sand up to $500 \mu \mathrm{m}$ necessitating an $11^{\circ}$ slope and volumetric concentrations of $17 \%$. Froude numbers are not reported. However, consideration of the flow height and associated depth-averaged velocity, and excess density (280 $\mathrm{kg} \mathrm{m}^{-3}$ ) suggests that flow is subcritical, in accordance with the lack of observations of a hydraulic jump.

The flow relaxation model is in part conceptual as there are a lack of direct measurements of the vertical and lateral flow components, as the velocity measurement was undertaken using one-component probes orientated at $60^{\circ}$ relative to the maximum bed slope. Furthermore, in order to derive 


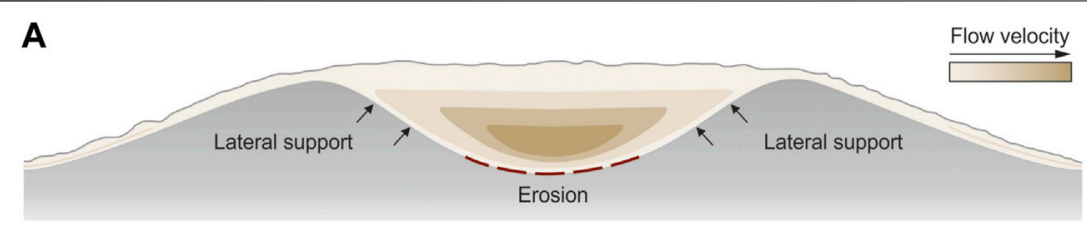

B

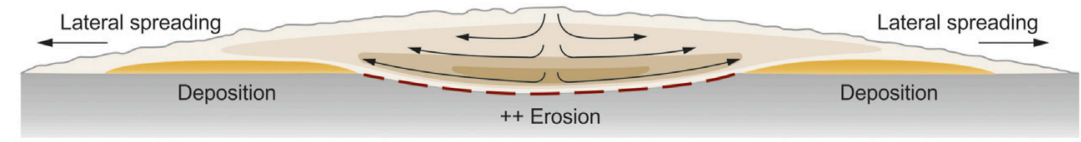

FIGURE 7|The flow relaxation model. (A) Confined flow in a reference experiment at the same point on the slope as in (B). (B) Largely unconfined flow downstream of a loss of confinement, marked by flow relaxation consisting of lateral spreading and downward movement of flow towards the base, lowering the position of the downstream velocity maximum, and therefore increasing basal shear stresses and enhancing erosion. Modified from Pohl et al. (2019).

downstream velocities from such angled probes an assumption is made that net vertical velocity, and net lateral velocity, are zero, in agreement with flows of constant width and thickness on slopes (e.g., Gray et al., 2005). Consequently, if the model is correct that there is a net vertical motion of fluid towards the bed because of lateral flow, which increases in magnitude as the bed is approached (Figure 7B), then the calculated downstream velocities used to predict bed shear stresses will be inaccurate, with inaccuracies increasing towards the bed. This raises questions about the validity of the shear stress calculations given the sensitivity of these to the shapes of the velocity profiles (e.g., Yu and Tan, 2006). An alternative explanation, or a potential additional process that may contribute to the observed processes in the Pohl et al. (2019) experiments, is density stratification induced changes in velocity profiles in response to the velocity decrease. Stratification is known to increase as flows decelerate, and this leads to a lowering of the velocity maximum in turbidity currents (Wells and Dorrell, 2021). Given the very high depth-averaged concentrations ( $17 \%$ by volume) in these experiments, then this effect is likely to be considerable. In contrast, real-world flows are estimated to have bulk densities 1 to 2 orders of magnitude lower than these experiments (e.g., Konsoer et al., 2013; Peakall and Sumner, 2015; Simmons et al., 2020), and therefore this process will be less important. That said, stratification may lead to the lowermost parts of flows still having high sediment concentrations in certain cases (Peakall and Sumner, 2015; Wells and Dorrell, 2021), and thus this process may be important towards the base of natural turbidity currents.

Lang et al. (2021) also undertook density current experiments with a similar instantaneous transition from a channel to a slope $\left(10^{\circ}\right)$, in the absence of a slope break. The experiments, however, differ in their parameters relative to those of Pohl et al. (2019). The Lang et al. (2021) flows were supercritical throughout the measurement section, were depositional (several $\mathrm{cm} \mathrm{hr}^{-1}$ ), and were mixed saline-particulate suspensions (excess density $50 \mathrm{~kg} \mathrm{~m}^{-3} 1 / 3 \mathrm{rd}$ sediment, 2/3rd saline). The sediment built a channel extending beyond the fixed channel, and this widened over a distance of a metre from $\sim 20 \mathrm{~cm}$ (the fixed channel width) to $\sim 36 \mathrm{~cm}$; this channel was filled with antidunes. Downstream of this widening constructional channel mouth is a lobe similarly covered in antidunes in proximal areas, and asymmetrical inphase bedforms in distal parts, interpreted as supercritical dunes (Fedele et al., 2016; Lang et al., 2021). Lang et al. (2021) used a 3component velocity measurement technique, and observed no lowering of the velocity maximum, even though the flow expanded laterally by $\sim 8.9^{\circ}$ in the initial metre, and presumably continued with a similar expansion rate.

\section{Flows Across Slope Breaks in the Absence of Hydraulic Jumps}

Recent work by Spychala et al. (2020) and Pohl et al. (2020) have used the Shields scaling approach to examine the nature and extent of flow bypass at a slope break, with and without flow expansion at the channel termination, respectively. Pohl et al. (2020) used a two-dimensional setup with no flow expansion at the slope break and varied the up-dip and down-dip slope angles whilst maintaining a constant discharge and flow concentration ( $17 \%$ by volume). The work shows that the slope break angle alone is a poor guide for determining the length of the bypass zone. Instead, higher up-dip slope angles extend the bypass zone basinward, whilst the angle of the lower slope controls the thickness of the downdip deposits. A Froude number is only reported for a single case, giving a supercritical value of 2.3 (Pohl et al., 2020). However, there are a number of issues with this estimate: 1) the top of the flow does not appear to be captured (see Pohl et al., 2020, supplementary); 2) vertical velocities are assumed to be negligible even though the flow will decelerate and thicken across the slope break which by flow continuity will lead to significant vertical velocities. This leads to over-estimation of downstream velocities; 3 ) flow depth estimates are based on a bespoke methodology (see also Pohl et al., 2019), by taking the height to the point at which the velocity drops to half of that at the velocity maximum. This approach is equivalent to the widely used methodology for non-dimensionalising velocity profiles from runs with different flow depths (Launder and 

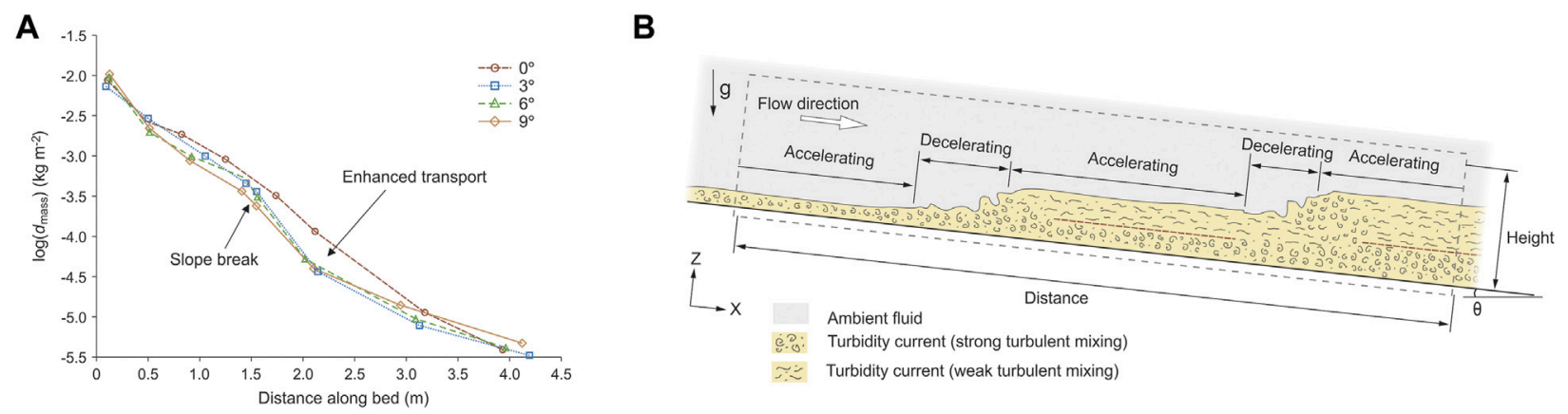

FIGURE 8 | (A) Profiles of sediment deposition (deposit mass per unit bed area; $d_{\text {mass }}$ ) with distance downstream for subcritical turbidity currents across a slope break onto a horizontal floor. These experiments did not show flow expansion, but demonstrated enhanced turbulence generation and development of periodic larger scale coherent flow structures downstream of the jump. Modified from Gray et al. (2005). (B) Schematic representation of a transcritical turbidity current showing a soft transition between supercritical and subcritical flow (i.e., without a hydraulic jump), consisting of a series of cascading instabilities. Modified from Salinas et al. (2020).

Rodi, 1983; Buckee et al., 2001; Gray et al., 2005). This method gives values approximately half of the true thickness (see Pohl et al., 2020, their Figure 5); 4) in turn, the depth-averaged velocity is calculated for that part of the flow below this depth, leading to a value approximately twice that of the whole flow. Adjusting for these aspects suggests that the flows were likely subcritical, in keeping with the absence of hydraulic jumps within the experiments (note that the upstream migrating "rollers" observed in a few experiments appear to be a reflected supercritical bore formed from a collapsing incoming subcritical flow; Edwards, 1993; Edwards et al., 1994).

The experiments of Spychala et al. (2020) allowed flow expansion at the channel terminus/slope break, and varied the downdip slope angle, flow concentration (13-19\% by volume) and discharge. They show that the CLTZ length increases with higher concentration and higher discharge flows, and decreases with increasing basin floor angle; this latter result is in contrast to the aforementioned 2D experiments of Pohl et al. (2020). Note that no Froude numbers are reported in Spychala et al. (2020). However, the absence of hydraulic jumps suggests that these flows are all subcritical.

Whilst the experiments of Pohl et al. (2020) and Spychala et al. (2020) examine the controlling parameters on bypass zone/CLTZ length, they do not describe the underlying flow mechanics. Gray et al. (2005), Gray et al. (2006) examined subcritical turbidity currents ( $1 \%$ volumetric concentration; $40-110 \mu \mathrm{m}$ size range) across slope breaks $\left(3^{\circ}, 6^{\circ}, 9^{\circ}\right)$ onto a horizontal floor, in a fixed width tank. As such, there was no flow expansion. Velocity was measured in a two-component (downstream and vertical/bednormal) grid. At, and immediately beyond, the slope break they showed that the basal part of the flow below the velocity maximum slowed rapidly, whilst the upper part was less affected. The rapidly slowing basal flow produced enhanced turbulence, whereas the upper part was characterised by the development of periodic large coherent flow structures. The currents were net depositional, but deposition was significantly reduced by about 1.75 channel widths downstream of the slope break (Figure 8A), and linked to enhanced sediment suspension caused by increased turbulence at the slope break (Gray et al., 2005). In the lowermost parts of the flow, mean bed normal (vertical) velocities at the slope break were towards the bed (see Gray et al., 2006, their Figure 9), and became upward directed by the point where sedimentation is reduced (see Gray et al., 2006, their Figure 5B). For a flow that is not net depositional, this additional turbulence, both in terms of the total kinetic energy and the large scale coherent structures, may be expected to lead to an erosional zone downstream of the slope break, with variations in turbulence potentially triggering localised scouring within this zone.

\section{Transition From Supercritical to Subcritical Flow Without a Hydraulic Jump}

In some experiments and simulations of coarse-grained supercritical turbidity currents encountering a slope break, a hydraulic jump was not observed (García, 1989; García, 1993; Kostic and Parker, 2006; Kostic and Parker, 2007). In such cases, where settling velocity and thus sedimentation are very high the flow has been shown to be unable to undergo a hydraulic jump (Kostic and Parker, 2006; Kostic and Parker, 2007). However, this situation is unlikely to apply to CLTZs, or CMEZs, given their dominantly erosional nature. Nevertheless recent work has illustrated that there may be a mechanism by which finergrained flows can transition from supercritical to subcritical flows in the absence of a hydraulic jump (Salinas et al., 2020). They used a direct numerical simulation of subaqueous dilute particulate density currents (concentration is not given; particles have zero settling velocity), on a constant slope $\left(0.72^{\circ}\right)$, and showed a change from supercritical to subcritical flow in the absence of a hydraulic jump. Salinas et al. (2020) referred to this as a 'soft transition', and it is associated with a transcritical flow characterised by a series of intermittent cascading instabilities (Figure 8B). Basal shear stress is shown to increase and decrease in a cyclical fashion reflecting these instabilities. Salinas et al. (2020) note that the associated cyclicity wavelengths ( 60-140 
flow depths; this will vary with slope angle) are consistent with sediment wave spacing. However, given more erosive conditions, this cyclicity might also be associated with periodic erosion. In these cases, there would then be a feedback between the flow and the aggradational/erosional bedforms, and it is unclear whether a transcritical flow state would be maintained.

\section{Summary of Physical Experiments, Numerical Simulations and Real-World Flow Measurements}

Process studies have identified a variety of mechanisms that may influence the nature of flows as they transition from channels to lobes. Many of these are dependent on the criticality of the flow, and the presence or absence of a pronounced break of slope. Supercritical flow on a relatively smooth slope produced channel mouth widening populated by a range of supercritical bedforms (i.e., a CMEZ) (Lang et al., 2021). Supercritical to subcritical transitions across a slope break may be associated with the production of a single hydraulic jump, as in plunge pools, if the incoming flow has a high Froude number (e.g., García, 1993) and the slope break angle is high (e.g., $>4^{\circ}$; Lee et al., 2002). Alternatively, an array of linked hydraulic jumps over broader CLTZs develop if the incoming flow has a Froude number closer to unity (Sumner et al., 2013; Dorrell et al., 2016) and likely a lower slope break angle. Single jumps across slope breaks are associated with decreased bed shear stress, and predicted enhanced sedimentation, downstream of the jump (García and Parker, 1989; García, 1993), although these are in 2D experiments that lack flow expansion. In contrast, arrays of hydraulic jumps have been shown to maintain bed shear stress downstream of the jumps (Dorrell et al., 2016).

If the up-dip flow is already subcritical, then channel mouth settings can be triggered by a slope break, a loss of confinement, or a combination of the two. Rapid deceleration of subcritical flow caused by a slope break has been shown to enhance turbulence generation at the base of the flow (Gray et al., 2005; Gray et al., 2006), albeit these were in $2 \mathrm{D}$ experiments. Where deceleration occurs as a result of flow expansion, in the absence of a slope break, bed shear stress is postulated to increase, as a result of flow relaxation (Pohl et al., 2019), and/or density stratification induced lowering of the downstream velocity maximum (Wells and Dorrell, 2021) if the flow is sufficiently dense, as argued herein.

Flows may undergo a transition from supercritical to subcritical without undergoing a hydraulic jump(s) (Kostic and Parker, 2006; Kostic and Parker, 2007; Salinas et al., 2020), albeit in some cases these are associated with rapidly depositing flows that will not typically be associated with CLTZs or CMEZs. Intriguingly, Salinas et al. (2020) show that this change in Froude number state can occur via a 'soft transition' of cascading instabilities that are associated with cyclical variations in bed shear stress over wavelengths of 10-100s of flow depths. We propose that this may offer an alternative or additional process to explain the arrays of erosive scours observed in many CLTZs.

\section{CHANNEL MOUTH SETTINGS INTERPRETED IN ANCIENT OUTCROP AND SUBSURFACE}

The dominance of erosion, lack of stratigraphic completeness, and minimal preservation within modern channel mouth settings highlights the difficulty in their identification in outcrop and subsurface datasets, despite their distinct seafloor morphology and features. Furthermore, palaeogeographic context is rarely sufficient to discount some degree of attachment between submarine channels and lobes at the time of deposition, differentiating scour- and channel-fills can be difficult (Figure 9), and basinward propagation of related channels suggests that the preservation potential of channel mouth setting should be low (Hodgson et al., 2016; Pemberton et al., 2016). Therefore, outcrop examples of interpreted plunge pools and CLTZs are rare. Nonetheless, there is a growing literature on interpreted exhumed CLTZs, and their stratigraphic expression range from (composite) erosion surfaces separating underlying lobes and overlying channel-levee systems (e.g., Gardner et al., 2003) to thicker records of deposition with scour-fills and aggradational beds (e.g., Navarro and Arnott, 2020)

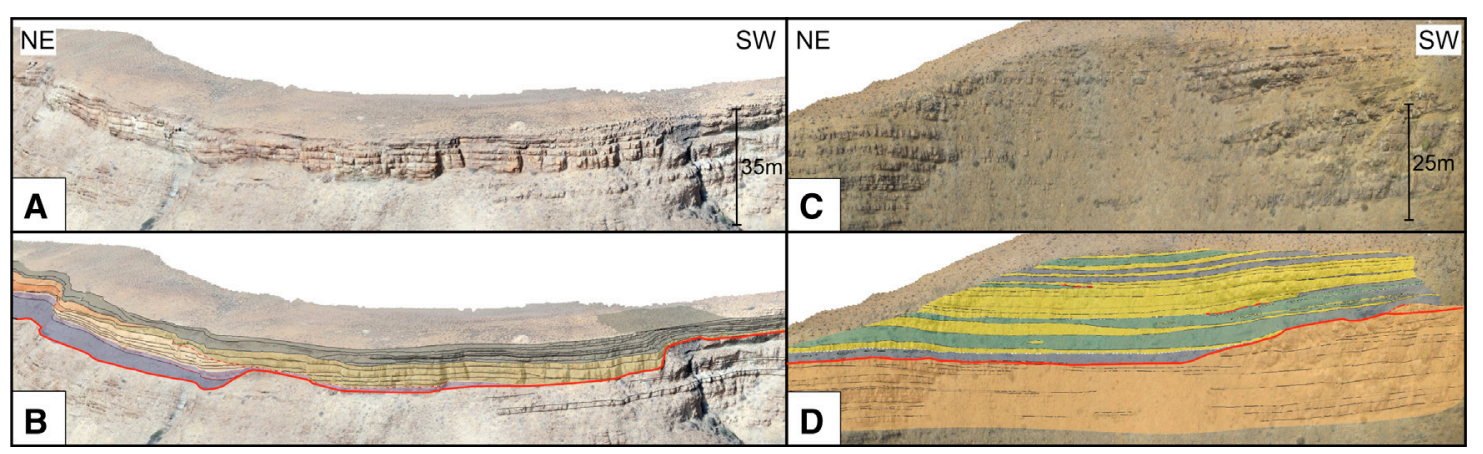

FIGURE 9 | Images from photogrammetric models built from uncrewed aerial vehicle images of giant scour-fills in interpreted channel-lobe transition zones. (A) uninterpreted and (B) interpreted images of scour-fill in Fan 3 at Kleine Reit Fontein, Tanqua Depocentre, Karoo Basin and (C) Uninterpreted and (D) interpreted images of a scour-fill in Unit A5 at Wilgerhout, Laingsburg Depocentre, Karoo Basin. Colours relate to sedimentary facies, which are described in detail in Hofstra et al. (2015). 


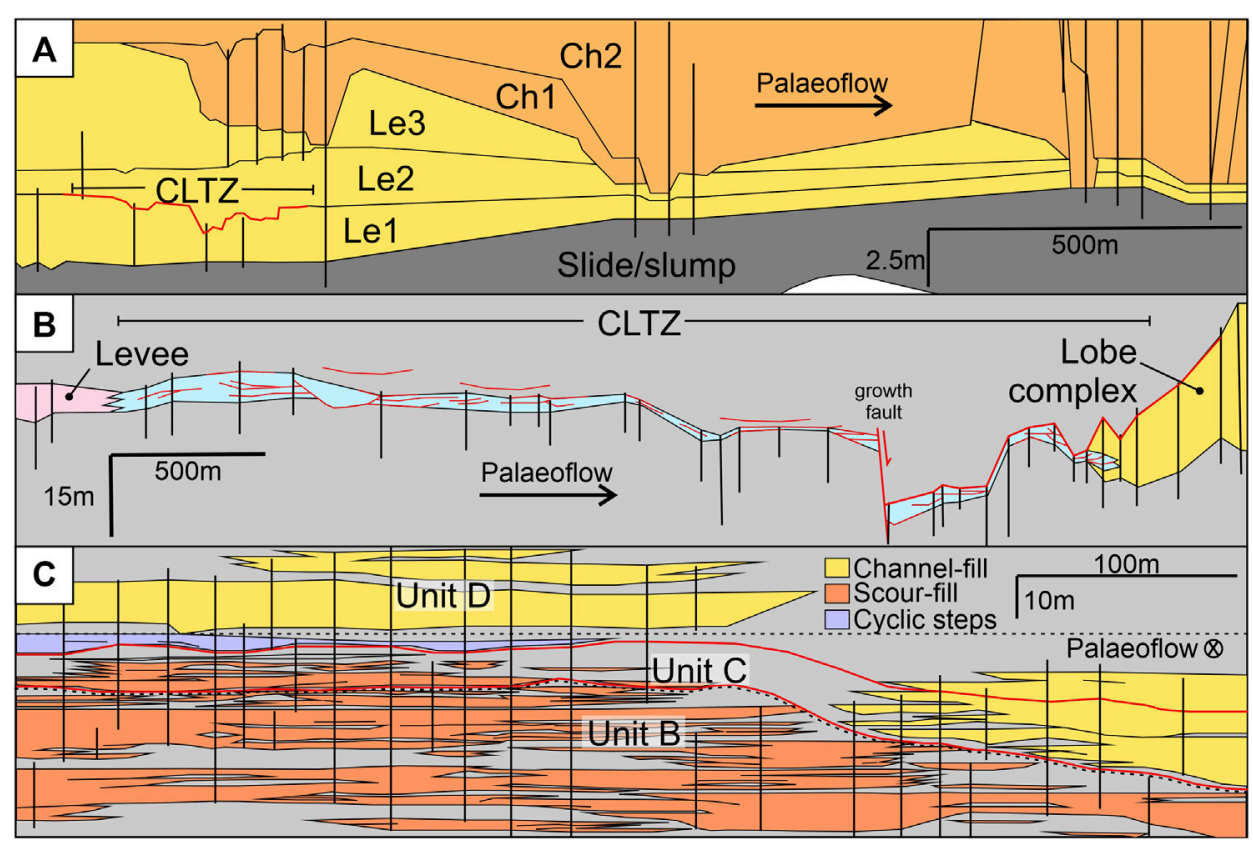

FIGURE 10 | Compilation of outcrop panels of interpreted channel mouth settings, where black vertical lines are locations of measured sections. (A) A CLTZ as a surface as the base of lobe element (Le) 2 at the Bridges of Ross outcrop, Loop Head Peninsula, County Clare, western Ireland (adapted from Pyles et al., 2014). (B) A thin CLTZ in Unit E3, Fort Brown Formation, Laingsburg depocentre, Karoo Basin, South Africa, in a base-of-slope location (adapted from Brooks et al., 2018). Red lines are scour surfaces, and the aquamarine unit is the interpreted CLTZ, which is $<10 \mathrm{~m}$ thick. Note the growth fault, and the abrupt thickening downdip of the sandrich lobe complex (yellow). (C) A thicker succession recording the overall progradation of a lower slope succession with a large number of scour-fills, and local cyclic steps, below and adjacent to stacking channel elements from the Tres Pasos Formation, Magallanes retroarc foreland basin in southern Chile (adapted from Pemberton et al., 2016). Herein we suggest that this is a candidate CMEZ.

(Figure 10). This range of expressions suggests that the transfer and preservation of different channel mouth settings into the rock record is characterised by a range of controls and physiographic configurations.

\section{Exhumed Plunge Pool-Fills}

Lee et al. (2004) interpret deep scour-fills in the Peïra Cava outlier (Eocene-Oligocene; Annot Sandstones), SE France, as plunge pool-fills. These decametre-thick sandstone bodies developed in base-of-slope settings in a foreland basin close to basin margins and immediately downstream from an inferred breakin-slope. The sandstone bodies comprise a complex basal unit of laterally pinching or inter-fingering debrites and turbidites, which is overlain abruptly by a single, thick normally graded turbidite. One sandstone body pinches out laterally in a few hundred metres and sits within a deep $(>20 \mathrm{~m})$ spoon-shaped erosional scour.

Henstra et al. (2016) document pervasive spoon-shaped scourand-fill features at the base of the depositional slope in the Middle Jurassic to Lower Cretaceous Wollaston Forland half-graben, NE Greenland. They interpret the scour-fills as plunge pool-fills that formed from (and filled by) high-density supercritical turbidity currents that were forced to decelerate and undergo a hydraulic jump at the base of steep slopes.

\section{Exhumed CLTZs as Surfaces}

Several studies suggest that the expression of the CLTZ in a stratigraphic succession is a single (or composite) erosion surface that separates underlying lobes from overlying channel fills and levees. For example, Gardner et al. (2003) use outcrops of the Permian Brushy Canyon Formation, Texas, United States, to interpret basinward then landward migration of the CLTZ by the vertical association of sandstone lobes overlain by an erosion surface and channel fills, which are capped by sandstone lobes. Hodgson et al. (2016) show several examples of frontal lobes abruptly overlain by external levee successions from the Permian Karoo Basin, which are used as evidence of basinward channel-levee propagation. The scoured surface mantled with mudclast lags separating the lobes and external levees is interpreted as the stratigraphic expression of the CLTZ. Pyles et al. (2014) used digital surveying and sedimentary logging to assess the juxtaposition of lobes and channel-fills at the Bridges of Ross outcrop in the Clare Basin, western Ireland. The upward succession at the Bridges of Ross outcrop begins with a slump (the Ross Slump), which is overlain by compensationallystacked lobe elements that are in turn overlain by channel-fill elements (Figure 10). This succession records the stratigraphic transition from basin-floor (upper Ross Sandstone) to lower slope (Gull Island Formation). The only CLTZ they identify at outcrop is the basal surface of one of the compensationally-stacked lobe elements, which is mantled by several closely spaced megaflutes (Figure 10).

\section{Exhumed Thin CLTZs ( $<10 \mathrm{~m}$ Thick)}

An example of a thin CLTZ is sub-unit E3 of the Fort Brown Formation, Karoo Basin, South Africa (Van der Merwe et al., 
2014). The outcrops preserve a juxtaposition of depositional and erosional elements within a $<10 \mathrm{~m}$-thick unit. Intraformational sand- and mud-clast deposits are located throughout the section and interpreted as lags that record sediment bypass (Brooks et al., 2018), and supports interpretation of an erosion-dominated CLTZ (Figure 10). Metre thick, but heavily scoured sandstone beds share affinities with subcritical sediment waves identified in an interpreted CLTZ in the older Unit B stratigraphy (Hofstra et al., 2018). Sand-rich hybrid beds are noted in the proximal lobe immediately down-dip of the CLTZ where sub-unit E3 thickens abruptly (Brooks et al., 2018). The mapping of internal erosion surfaces demonstrated migration, and contraction or expansion, of the CLTZ (Brooks et al., 2018). The presence of a growth fault in this base-of-slope setting likely increased the gradient change to form this well-preserved CLTZ (Figure 10).

\section{Exhumed Thick CLTZs ( $>10 \mathrm{~m}$ Thick)}

Thicker records of interpreted CLTZs, with aggradational beds in close association with scour-fill features, have been identified where outcrop quality permits up-dip channel-complexes and down-dip lobe complexes to be mapped (e.g., Ito, 2008; Hofstra et al., 2015; Pemberton et al., 2016) or are inferred from stratigraphic relationships (e.g., Navarro and Arnott, 2020). Hofstra et al. (2015) presented recognition criteria to distinguish (giant) scourfills from channel-fills to support interpretation of CLTZs in the Karoo Basin, South Africa. The preservation of the scour-fills (Figure 9) was attributed to their location with respect to the propagation direction of the feeder channel.

Navarro and Arnott (2020) document the stratigraphic transition from basin floor (Kaza Group) to slope (Isaac Formation) strata, which is marked by three stacked interpreted CLTZs. The lower and upper CLTZs contain more scour-fills. In contrast, the middle CLTZ has more tabular sandstone elements, which Navarro and Arnott (2020) interpret as a poorly-developed channel-lobe transition zone, resulting from inefficient, siliciclastic-rich depositional flows. The formation of multiple CLTZs with different characteristics is interpreted by Navarro and Arnott (2020) to record relative sea-level changes, and the associated changes in sediment supply and flow characteristics.

The preservation of a thicker stratigraphic record for CLTZs has been explained by high aggradation rates (e.g., Pemberton et al., 2016; Figure 10), tectonically-active settings (Ito, 2008; Mansor and Amir Hassan, 2021; Brooks et al., 2022), rapid abandonment or avulsion of feeder channels before erosion into the CLTZ (e.g., Hofstra et al., 2015; Brooks et al., 2018), or a large-scale passive margin setting allowing more net aggradation (Navarro and Arnott, 2020). Nonetheless, these studies also interpret lobes and channel-fills as part of the stratigraphic succession, which points to an aggrading and interfingering succession where the CLTZ is relatively fixed, and preserved as surfaces and thinner stratigraphic units as part of a thicker succession.

\section{Subsurface CLTZs}

There are additional challenges in the identification of channel mouth settings in the subsurface given the typical resolution of seismic reflection data, and the scarcity of core and well intersections. Hansen et al. (2021a) used core observations to support interpretation of a $12 \mathrm{~m}$ thick CLTZ in the late Cretaceous Lysing Formation, offshore Norway. Observations included the presence of erosion surfaces and abundance of crossstratified glauconite-rich sandstones interbedded with predominantly sandy bioturbated heterolithics, as well as the abundance of very fine- and medium-to coarse-grained sandstones, and the absence of fine-grained sand sizes. They interpreted the glauconite-rich cross-stratified bed types as bedforms that migrated, possibly at the base of scours, in a CLTZ setting. Based on the wells, seismic reflection data, including spectral decomposition, the CLTZ is constrained to a $5 \times 3 \mathrm{~km}$ area, and formed on a break-in-slope above a stepped post-rift slope profile.

Wang et al. (2020) employed high-resolution 3D seismic reflection data from the Qiongdongnan Basin (South China Sea) to document downstream changes in bedforms through an interpreted CLTZ. Wang et al. (2020) document scours (1.2-5.6 $\mathrm{m}$ deep) at the bifurcation points of distributive channels, and steps at the confluence points, which they interpret as forming by supercritical flows and hydraulic jumps. Although in the absence of core data, the sedimentary facies of the seismically resolved bedforms remains unconstrained.

\section{DISCUSSION}

\section{A New Classification of Submarine Channel Mouth Settings}

Seafloor examples highlighted herein illustrate a range of morphologies and deposits likely resulting from different flow processes. Erosional (cyclic step) and depositional (sediment wave) bedforms dominate CMEZs from delta foreset slopes, continental slopes, and associated canyons (e.g., Covault et al., 2017; Vendettuoli et al., 2019; Fildani et al., 2021). The presence of these bedforms suggests that turbidity currents exiting or overbanking low-relief channels are supercritical, and may either undergo hydraulic jumps or still be supercritical at the point of flow expansion, creating upper flow regime bedforms. For example, in settings like the La Jolla Fan (Maier et al., 2020) and Squamish Delta (Vendettuoli et al., 2019), without a clear single break in gradient across a relatively high slope, the flows that formed the widening channel, sediment waves, and erosional step morphologies were likely supercritical, resulting in a CMEZ where flows lost confinement.

Base of slope breaks, or changes in gradient on the basin floor, appear to favour flows that are either already subcritical, or are sites for the rapid transition of flows from supercritical to subcritical conditions (Figure 11). This results in the development of broad "classic" CLTZs, such as the Rhône Fan (e.g., Droz et al., 2020), with multiple scours and sediment waves. Where the incoming slope gradient is particularly high (e.g., $>4^{\circ}$; Lee et al., 2002), a single hydraulic jump is likely to form and develop plunge pool morphology at the base of slope (Figure 11). Conversely, large canyon-fan systems where channels extend 


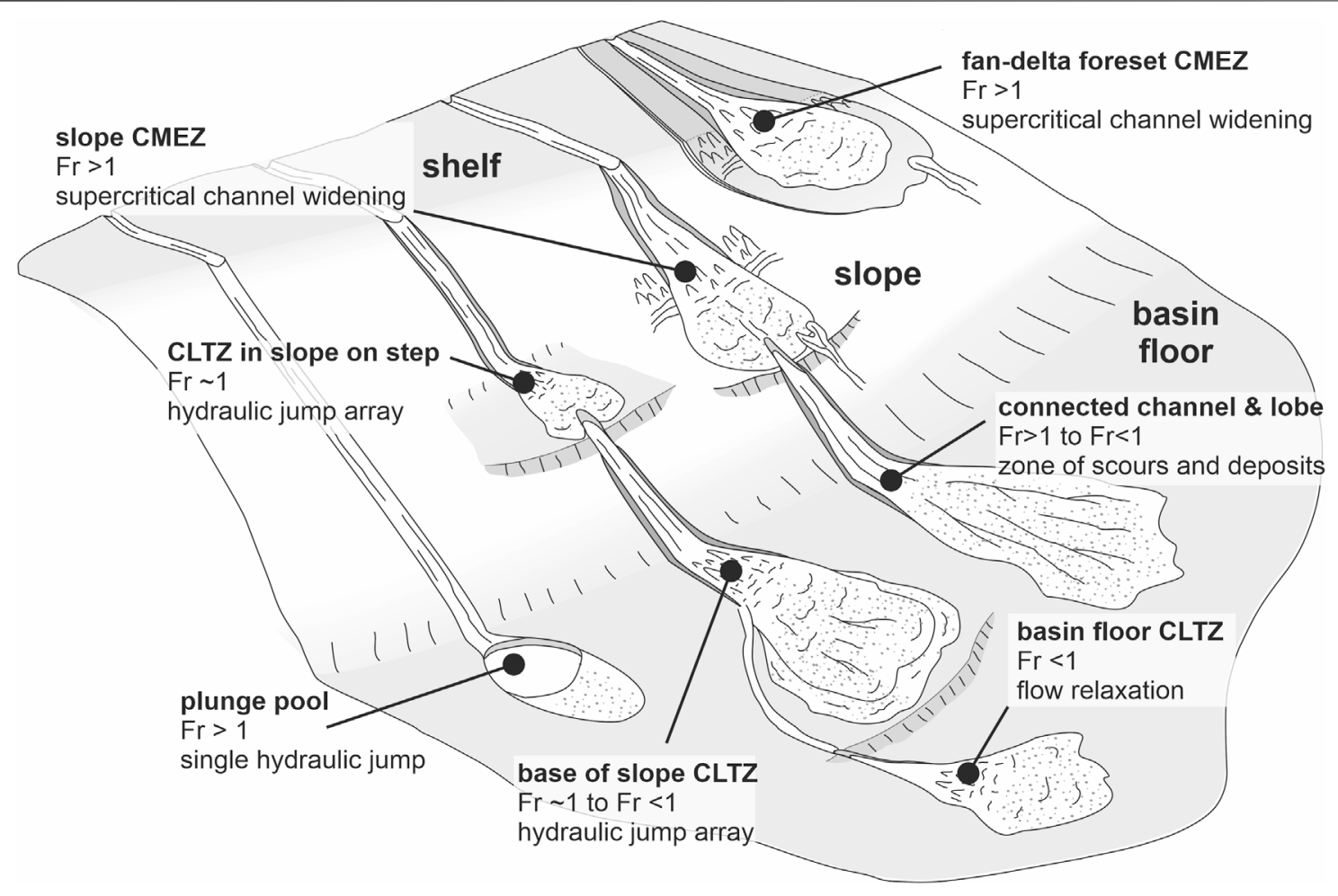

FIGURE 11 | A synthesis of different types of channel mouth settings, their likely physiographic location, and dominant flow type in terms of flow criticality. Channel mouth expansion zones (CMEZs) are present on steep slopes, including foresets of fan deltas, and are dominated by supercritical flows and bedforms. Plunge pools are located at the base of steep slopes forming a single hydraulic jump, and with flow having supercritical Froude numbers. Note that plunge pools can also form within canyons where they are related to features such as knickpoints. Channel-lobe transition zones (CLTZs) with hydraulic jump arrays form at breaks-of-slope, with supercritical flows closer to unity. Subcritical CLTZs associated with flow relaxation, typically form in relatively distal locations at points of flow expansion. Channels and lobes can also be connected, without a transition zone developing, at the base of slope with mixed erosional and depositional processes.

hundreds of kilometres onto the relatively flat basin floor, such as the Congo example (Dennielou et al., 2017), may be prone to subcritical flows, or "soft transitions", that facilitate linked channel-lobe complexes and the absence of CLTZs (Figure 11).

The importance of supercritical aggradational bedforms in CLTZs that develop beyond the slope break is less clear. In part, this is due to the lack of high-resolution studies from these more basinward locations. Nonetheless, the amount of gradient change at a break in slope appears to be a key driver of channel mouth morphology and processes, with high gradients along channel reaches related to plunge pools (e.g., Lee et al., 2002) or development of a CLTZ (e.g., Droz et al., 2020).

The present analysis suggests a four-fold classification of channel mouth settings, expanding on the concept of supercritical and subcritical CLTZs of Postma et al. (2016). These four types are: 1) supercritical CMEZs on slopes; 2) plunge pools at steep slope breaks with high incoming supercritical Froude numbers; 3) CLTZs with arrays of hydraulic jumps at slope breaks with incoming supercritical Froude numbers closer to unity; and, 4) subcritical CLTZs associated with slope breaks and or flow expansion (Figure 11). In turn, these types of channel mouth settings will preferentially be associated with different physiographic positions, reflecting changes in flow Froude number and slope variability (e.g., Pirmez and Imran, 2003; Dorrell et al., 2013). On continental slopes, flows are likely supercritical and CMEZs may be favoured. Hydraulic jump arrays, or plunge pools are likely favoured at the continental slope break, and enhanced turbulence and a lowered velocity maximum (flow relaxation/density stratification induced lowering) would be favoured in distal transitions out on the basin floor (Figure 11). Channels and lobes can be connected, without a transition zone developing, where erosional and depositional processes alternate (Figure 11).

\section{Dynamic Settings and Building a Stratigraphic Record}

The linked morphology and process classification provides useful ideas for further study. However, it should be noted that they can occur within a single system on the seafloor (e.g., CMEZ at the head of the San Gabriel Fan CLTZ, Maier et al., 2018). Furthermore, CLTZs and CMEZs appear to be complicated areas of flow-topography interactions that change flow-byflow. This raises the issue of preservation potential of morphologies and deposits observed on the modern seafloor. Despite the longevity of some scours (Macdonald et al., 2011a), 
the dominantly erosional CLTZs and CMEZs have low potential to accumulate over time (e.g., Vendettuoli et al., 2019) or be preserved in the rock record (e.g., Pemberton et al., 2016). However, recognising channel mouth settings is an important aspect of deciphering system dynamics because erosion (e.g., scouring, incipient channels, knickpoints) can propagate throughout the system (Hodgson et al., 2016; Heijnen et al., 2020).

Given their morphodynamic differences, can differences in flow types, and preserved bedforms, be used to distinguish CMEZs and CLTZs? Currently, there is a disconnect between recent high-resolution studies of CMEZs on the slope and/or associated with canyons (Figures 3, 4), and the most comprehensive ancient studies, which are CLTZs on, or beyond, the base-of-slope (Figure 10). The modern studies reinforce the importance of erosion and scoured surfaces, and the presence of supercritical bedforms in characterising channel mouths in CMEZs on the slope (e.g., Carvajal et al., 2017; Maier et al., 2020; Figure 11). The transfer of CLTZs into the stratigraphic record has been interpreted in several outcrop studies. Based on these examples, recognition criteria for CLTZs in the rock record include: a typically thin stratigraphic expression; amalgamated erosional features; coarse-grained lag deposits; aggradational bedforms (i.e., subcritical sediment waves); soft-sediment deformation; interfingered or juxtaposed erosional and depositional elements; and sand-rich hybrid beds in proximal lobes (e.g., Bravo and Robles, 1995; Ito, 2008; Pyles et al., 2014; Van der Merwe et al., 2014; Hofstra et al., 2015; Brooks et al., 2018; Hofstra et al., 2018; Brooks et al., 2022). However, recognition criteria for distinguishing CLTZs and CMEZs in the rock record have not been established.

\section{Where Are the Exhumed CMEZs?}

The documentation of CMEZs on the modern seafloor provide an alternative configuration for interpretation of outcrops where surfaces and successions do not conform to either channel-levee or lobe systems. Given the steeper slopes that may be required for CMEZ development, and the focus on supercritical bedforms in the rock record, many of the well-studied exhumed tectonicallyactive sedimentary basins that host deep-water successions are prime candidates to consider the stratigraphic transfer of CMEZs, and their recognition criteria. Furthermore, some interpreted exhumed CLTZs have identified supercritical bedforms (Pemberton et al., 2016; Postma et al., 2016; Postma et al., 2021). Therefore, given the propensity of supercritical bedforms identified in modern CMEZs, could the presence of subcritical aggradational or supercritical bedforms be a discriminating criterion between CLTZs and CMEZs, respectively?

Challenges in recognizing exhumed CMEZs include identification of the basal surface, which is likely to have a high aspect ratio, and be composite, with scour-fills inside and outside the surface. To document this requires excellent outcrops with good 3D control. The associated up-dip channels might have propagated basinward and the headless channels imaged on the modern seafloor might work updip and connect, removing much of the axial record. Furthermore, resolving a (lower) slope setting versus basin-floor requires excellent palaeogeographic context. Nonetheless, we propose that several exhumed examples are reassessed as CMEZs based on their characteristics, including the presence of supercritical bedforms.

Postma et al. (2021) document a range of supercritical flow bedforms, including intercalated antidunes and mouth bar-related chute-and-pool-like structures, and upslope migration of hydraulic jump zones. These bedforms are preserved in a relatively short $(100 \mathrm{~s} \mathrm{~m})$ interpreted CLTZ that developed toward the base of a fandelta foreset slope (the Eocene Sant Llorenç del Munt clastic wedge, near El Pont de Vilomara, NE Spain). Postma et al. (2021) sketch a flaring channel mouth setting, although outcrop limitations do not permit the planform shape to be confidently constrained. However, the foreset setting and high proportion of supercritical bedforms and erosion surfaces support an alternative interpretation of a CMEZ.

Hansen et al. (2021b) document an example of a high aspect ratio erosion surface in Unit 5 of the Permian Skoorsteenberg Formation (Tanqua Karoo, South Africa), which they interpret as a composite scour overlain by lobes. The $3-4 \mathrm{~km}$ wide, $1-2 \mathrm{~km}$ long, and up to $28 \mathrm{~m}$ deep basal surface, which is mantled locally with mud-clast conglomerates (lags), widens and shallows downdip, and is above a slope, as expected in a CMEZ. However, they do not report the presence of scour-fills or supercritical bedforms outside the basal surface.

Pemberton et al. (2016) interpret scour-fills either in front of (Unit B), or lateral to (Unit C), multiple submarine channel-fills from the Tres Pasos Formation (Upper Cretaceous) of the Magallanes retroarc foreland basin in southern Chile (Figure 10). The Arroyo Picana outcrop is located $\sim 40 \mathrm{~km}$ basinward of coeval shelf-edge deposits toward the lower portion of a high-relief $(>900 \mathrm{~m})$ slope. Interestingly, in Unit $\mathrm{C}$ along with scour-fills there are also cross-stratified sandstone bodies with positive-relief that record a palaeoflow at a high angle to the adjacent channel-fill. Pemberton et al. (2016) interpret these sandstones as a bedform with back-set cross-stratification formed by cyclic steps or antidunes. They interpret the stratigraphic architecture as a record of basinward progradation that preserves a channel-lobe transition zone around a break-in-slope. An alternative interpretation, which is consistent with the association of scour-fills and cyclic steps preserved in an elevated position adjacent to stacked channel-fills, is that Unit $\mathrm{C}$ records the lateral margin of a CMEZ on the lower slope.

The Ross Sandstone (Namurian) crops out along sea cliffs of the Loop Head Peninsula western Ireland. The interpretation and significance of extensive ( $>700 \mathrm{~m}$ wide) erosion surfaces mantled with megaflutes in the Ross Sandstone, County Clare, Ireland, has been debated (e.g., Chapin et al., 1994; Elliott, 2000a; Elliott, 2000b; Lien et al., 2003). The erosional bedforms occur on multiple stratigraphic surfaces and are associated with channel-fills and lobes (e.g., Pyles 2008; Macdonald et al., 2011b; Straub and Pyles, 2012). The Ross Sandstone preserves stacked high aspect ratio erosion surfaces with megaflutes, such as Ross Bay (Lien et al., 2003) and Kilbaha Bay (Chapin et al., 1994; Elliott, 2000a; Elliott, 2000b; Straub and Pyles, 2012). We suggest that the composite nature of these high aspect ratio erosion surfaces mantled with megaflutes are consistent with an 
interpretation as CMEZs. The presence of supercritical or subcritical depositional bedforms in the underlying and overlying sandstones is hindered by the dominantly structureless nature of the sandstones in the Ross Formation, although dune-scale straight-crested bedforms are observed adjacent to megaflutes on one of the inaccessible faces (Elliott, 2000b, their Figure 6). Furthermore, the change in character across the high aspect ratio surface(s) needs detailed documentation.

Identification of exhumed CMEZs is key to investigate outstanding questions, such as the recognition of the depositional bedforms that develop within the zones of expansion, which are biased towards CLTZs, and the age relationships of erosional and depositional bedforms that develop inside and outside the zone of expansion. In the Magallanes Basin example (Pemberton et al., 2016), the scour-fills and cyclic steps lie above erosion surfaces that confine adjacent channel elements. The exact age relationships are difficult to unravel but support the interpretation that bedforms developed on the flanks of a CMEZ as the adjacent channels propagated basinward. In both the Karoo Basin and Ross Sandstone examples, the architecture of sandstones overlying the high aspect ratio erosion surface is predominantly lobes. This might be because there was no further, or limited, propagation of channel systems, and therefore the high aspect ratio composite erosion surfaces remain well preserved. However, the formation of high aspect ratio surfaces in CMEZs also lend themselves to infilling by lobes if flows become more depositional (less efficient) due to autogenic or allogenic controls (Hansen et al., 2021b). The implication is that for CMEZs preserved in the rock record we are left primarily with the (composite) erosion surface, and the associated bedforms are poorly preserved. In contrast, the candidate CMEZ documented by Postma et al. (2021) has good preservation of supercritical flow bedforms, which can be attributed to the rapid rates of progradation in a fan-delta foreset setting.

\section{Future Opportunities for Channel Mouth and CLTZ Research}

Seafloor examples will continue to be a key component of channel mouth studies, particularly as acquisition methods improve. Highresolution imaging of more submarine fans, channel mouths, CLTZs, and CMEZs, will illuminate whether features imaged in sparse high-resolution datasets (i.e., Macdonald et al., 2011a; Droz et al., 2020; Maier et al., 2020) are common across systems and settings. Increasing coverage and resolution of seafloor examples offers the opportunity to link seafloor examples with the scale of outcrop studies and provide plan-view analogues to ancient examples. Specifically, such studies are needed to evaluate the presence of CMEZs and related bedforms (e.g., laterally continuous erosional steps) in ancient outcrop examples.

Considerable opportunities also exist for future instrumentation to advance our understanding of flow processes where channels transition into lobes and provide constraints for experimental and numerical studies. Likewise, the increasing recognition of the influence of oceanographic currents on many deep-sea deposits, including turbidites (e.g., Stow and Smillie, 2020 and references therein), highlights the opportunities for future studies of current-influenced channel mouth settings, hybrid fan-drift systems (e.g., Hikurangi Fan; Lewis, 1994), and high-latitude systems (e.g., Ó Cofaigh et al., 2006) to identify and understand modern and ancient deposits.

We have primarily focused on siliciclastic depositional systems, but lobes can also be deposited from deep-sea canyons and channels in carbonate systems. Carbonate lobes can occur at the base of slope, though often with the influence of contour currents (e.g., Mulder et al., 2012; Reijmer et al., 2015). In some cases, the lack of carbonate lobe deposition is linked to current activity (e.g., Recouvreur et al., 2021). Carbonate basin floor settings tend to be drifts instead of lobes (Reijmer et al., 2015), which may be one contributing factor to why carbonate channel mouth examples are less prevalent than siliciclastic examples. Nevertheless, there seems to be abundant opportunity in the future, with increasing seafloor mapping and resolution, to investigate channel mouth settings in carbonate systems.

Detailed outcrop research on CLTZs has primarily focused on large, relatively tectonically-quiescent basins associated with mature passive margins or thermal sag basins, and influenced by glacial-interglacial cycles, such as the Karoo Basin in South Africa (e.g., Van der Merwe et al., 2014; Hofstra et al., 2015; Brooks et al., 2018). Therefore, it is important to understand if these same models can be applied to tectonically-active basins (e.g., Mansor and Amir Hassan, 2021; Brooks et al., 2022), such as forearc or retroarc foreland basins, formed in different climatic conditions in both modern environments and in the rock record. Indeed, tectonically-active basin-fills are likely to host CMEZs given the steeper slopes. In summary, identification of exhumed examples of different types of channel mouth settings will drive forward a range of recognition criteria, which at present is biased towards CLTZs.

\section{CONCLUSION}

The mouths of submarine channels are a poorly understood but crucial part of the source-to-sink sediment transport route where sediment gravity flows undergo major changes in their behaviour as confinement decreases. We integrate physical experiments, numerical modelling, and observations of modern and ancient systems, to develop insights into channel mouth settings, and their transfer into the stratigraphic record. We review the wide range of different experimental configurations that have focussed on understanding changes in process behaviour as flows exit channels. An increasing number of studies of modern systems suggest that the classic channel-lobe transition zone (CLTZ) of Wynn et al. (2002a) is one type in a range of configurations. We propose four types of channel mouth setting: 1) channel mouth expansion zones (CMEZs) that form on steep slopes and in the absence of a pronounced break in slope, and are associated with supercritical bedforms; 2) plunge pools that form at steep slope breaks in both siliciclastic and carbonate systems, with high incoming supercritical Froude numbers; 3) CLTZs with arrays of 
hydraulic jumps at slope breaks with incoming supercritical Froude numbers close to unity; and, 4) subcritical CLTZs associated with slope breaks and/or flow expansion, that are the more basinward style of channel mouth setting.

Identification of the stratigraphic record of channel mouth settings is complicated by the propagation, and avulsion, of channels. Nonetheless, recent studies from ancient outcrop and subsurface systems have interpreted CLTZs, although candidate exhumed CMEZs that meet the criteria established from modern systems are postulated here, and warrant re-examination. Recent years have seen significant advances in our process understanding of these channel mouth settings. However, the total number of studies remains small, and the potential parameter space large, thus there remains much to discover.

\section{AUTHOR CONTRIBUTIONS}

$\mathrm{DMH}$, JP, and KLM coordinated the work. JP led review of experimental work, KLM led review of modern systems, and $\mathrm{DMH}$ led review of ancient systems. All authors contributed to writing the Discussion, and design and development of the figures.

\section{REFERENCES}

Alexander, J., Bridge, J. S., Cheel, R. J., and Leclair, S. F. (2001). Bedforms and Associated Sedimentary Structures Formed under Supercritical Water Flows over Aggrading Sand Beds. Sedimentology 48, 133-152. doi:10.1046/j.13653091.2001.00357.x

Babonneau, N., Savoye, B., Cremer, M., and Klein, B. (2002). Morphology and Architecture of the Present canyon and Channel System of the Zaire Deep-Sea Fan. Mar. Pet. Geology. 19, 445-467. doi:10.1016/s0264-8172(02)00009-0

Bonnel, C., Dennielou, B., Droz, L., Mulder, T., and Berné, S. (2005). Architecture and Depositional Pattern of the Rhône Neofan and Recent Gravity Activity in the Gulf of Lions (Western Mediterranean). Mar. Pet. Geology. 22, 827-843. doi:10.1016/j.marpetgeo.2005.03.003

Bourget, J., Zaragosi, S., Mulder, T., Schneider, J.-L., Garlan, T., Van Toer, A., et al. (2010). Hyperpycnal-fed Turbidite Lobe Architecture and Recent Sedimentary Processes: A Case Study from the Al Batha Turbidite System, Oman Margin. Sediment. Geology. 229, 144-159. doi:10.1016/j.sedgeo.2009.03.009

Bravo, J. C. V., and Robles, S. (1995). "Large-scale Mesotopographic Bedforms from the Albian Black Flysch, Northern Spain: Characterization, Setting and Comparison with Recent Analogues," in Atlas of Deep-Water Environments: Architectural Styles in Turbidite Systems. Editors K. T. Pickering, R. N. Hiscott, N. H. Kenyon, F. R. Lucchi, and R. D. A. Smith (London: Chapman \& Hall), 216-226. doi:10.1007/978-94-011-1234-5_32

Brooks, H. L., Hodgson, D. M., Brunt, R. L., Peakall, J., Hofstra, M., and Flint, S. S. (2018). Deep-Water Channel-Lobe Transition Zone Dynamics: Processes and Depositional Architecture, an Example from the Karoo Basin, South Africa. Geol. Soc. Am. Bull. 130, 1723-1746. doi:10.1130/B31714.1

Brooks, H. L., Ito, M., Zuchuat, V., Peakall, J., and Hodgson, D. M. (2022). Channel-lobe Transition Zone Development in Tectonically-Active Settings: Implications for Hybrid Bed Development. Accepted at The Depositional Record. doi:10.1002/dep2.180

Buckee, C., Kneller, B. C., and Peakall, J. (2001). "Turbulence Structure in Steady, Solute-Driven Gravity Currents," in Particulate Gravity Currents. Editors W.D. McCaffrey, B.C. Kneller, and J. Peakall (Oxford: International Association of Sedimentologists Special Publication), 31, 173-187.

Carvajal, C., Paull, C. K., Caress, D. W., Fildani, A., Lundsten, E., Anderson, K., et al. (2017). Unraveling the Channel-Lobe Transition Zone with HighResolution AUV Bathymetry: Navy Fan, Offshore Baja California, Mexico. J. Sed. Res. 87, 1049-1059. doi:10.2110/jsr.2017.58

\section{FUNDING}

JP thanks the Natural Environment Research Council (NERC) for funding that supported the work on hydraulic jump arrays in the Black Sea (Grants NE/F020511/1, NE/F020120/1, and NE/ F020279/1), and on megaflute erosion surfaces (NERC CASE Studentship NER/S/A/2006/14147 at the University of Leeds, with the National Oceanography Centre (NOC), Southampton as the CASE partner). KLM is supported by the Marine Geological Resources Programme at the National Institute of Water and Atmospheric Research (NIWA).

\section{ACKNOWLEDGMENTS}

Editor Fabiano Gamberi, and reviewers Juraj Janočko and Luigi Jovane are thanked for their constructive comments on the manuscript. We thank Gareth Keevil and Natasha Peakall for discussion and analysis, and David Lee for drafting Figures 1, 6-8 and 11. We thank V2Geo for hosting a publically available version of the Virtual Outcrop Model of Figures 9C,D at https://v3geo.com/model/297.

Chapin, M. A., Davies, P., Gibson, J. L., Pettingill, H. S., Zelt, F. B., and Mutti, E. (1994). "Reservoir Architecture of Turbidite Sheet Sandstones in Laterally Extensive Outcrops, Ross Formation, Western Ireland," in Submarine Fans and Turbidite Systems: Sequence Stratigraphy, Reservoir Architecture and Production Characteristics, Gulf of Mexico and International: Gulf Coast Section Society for Sedimentary Geology, GCSSEPM Foundation Annual Bob F. Perkins Research Conference Proceedings. Editors P. Weimer, A. H. Bouma, and P. F. Perkins. Tulsa, Oklahoma: SEPM Society for Sedimentary Geology, 15, 53-68. doi:10.5724/gcs.94.15.0083

Clare, M. A., Hughes Clarke, J. E., Talling, P. J., Cartigny, M. J. B., and Pratomo, D. G. (2016). Preconditioning and Triggering of Offshore Slope Failures and Turbidity Currents Revealed by Most Detailed Monitoring yet at a Fjord-Head delta. Earth Planet. Sci. Lett. 450, 208-220. doi:10.1016/j. epsl.2016.06.021

Covault, J. A., Normark, W. R., Romans, B. W., and Graham, S. A. (2007). Highstand Fans in the California Borderland: The Overlooked Deep-Water Depositional Systems. Geology 35, 783-786. doi:10.1130/g23800a.1

Covault, J. A., Kostic, S., Paull, C. K., Sylvester, Z., and Fildani, A. (2017). Cyclic Steps and Related Supercritical Bedforms: Building Blocks of DeepWater Depositional Systems, Western North America. Mar. Geology. 393, 4-20. doi:10.1016/j.margeo.2016.12.009

Dartnell, P., Driscoll, N. W., Brothers, D., Conrad, J. E., Kluesner, J., Kent, G., et al. (2015). Color Shaded-Relief Bathymetry, Acoustic Backscatter, and Selected Perspective Views of the Inner continental Borderland, Southern California. U.S. Geological Survey, Scientific Investigations. Map 3324, 2 sheets.

De Leeuw, J., Eggenhuisen, J. T., and Cartigny, M. J. B. (2016). Morphodynamics of Submarine Channel Inception Revealed by New Experimental Approach. Nat. Commun. 7, 10886. doi:10.1038/ncomms10886

Dennielou, B., Droz, L., Babonneau, N., Jacq, C., Bonnel, C., Picot, M., et al. (2017). Morphology, Structure, Composition and Build-Up Processes of the Active ChannelMouth Lobe Complex of the Congo Deep-Sea Fan with Inputs from Remotely Operated Underwater Vehicle (ROV) Multibeam and Video Surveys. Deep Sea Res. Part Topical Stud. Oceanography 142, 25-49. doi:10.1016/j.dsr2.2017.03.010

Deptuck, M. E., and Sylvester, Z. (2018). "Submarine Fans and Their Channels, Levees, and Lobes," in Submarine Geomorphology. Editors A. Micallef, S. Krastel, and A. Savini (Cham: Springer), 273-299. doi:10.1007/978-3-319-57852-1_15

Dorrell, R. M., Darby, S. E., Peakall, J., Sumner, E. J., Parsons, D. R., and Wynn, R. B. (2013). Superelevation and Overspill Control Secondary Flow Dynamics in Submarine Channels. J. Geophys. Res. Oceans 118, 3895-3915. doi:10.1002/jgrc. 20277 
Dorrell, R. M., Peakall, J., Sumner, E. J., Parsons, D. R., Darby, S. E., Wynn, R. B., et al. (2016). Flow Dynamics and Mixing Processes in Hydraulic Jump Arrays: Implications for Channel-Lobe Transition Zones. Mar. Geology. 381, 181-193. doi:10.1016/j.margeo.2016.09.009

Droz, L., Jégou, I., Gillet, H., Dennielou, B., Bez, M., Canals, M., et al. (2020). On the Termination of Deep-Sea Fan Channels: Examples from the Rhône Fan (Gulf of Lion, Western Mediterranean Sea). Geomorphology 369, 107368. doi:10.1016/j.geomorph.2020.107368

Edwards, D. A., Leeder, M. R., Best, J. L., and Pantin, H. M. (1994). On Experimental Reflected Density Currents and the Interpretation of Certain Turbidites. Sedimentology 41, 437-461. doi:10.1111/j.1365-3091.1994. tb02005.x

Edwards, D. A. (1993). Turbidity Currents: Dynamics, Deposits and Reversals. Berlin: Springer-Verlag, 174.

Elliott, T. (2000a). Megaflute Erosion Surfaces and the Initiation of Turbidite Channels. Geology 28, 119-122. doi:10.1130/0091-7613(2000)028<0119: mesati>2.3.co;2

Elliott, T. (2000b). "Depositional Architecture of a Sand-Rich, Channelized Turbidite System: The Upper Carboniferous Ross Sandstone Formation, Western Ireland," in Deep-water Reservoirs of the World. GCSSEPM Foundation 20th Annual Research Conference, Tulsa, Oklahoma, December 3-6, 2000. Editors P. Weimer, R.M. Slatt, J. Coleman, N.C. Rosen, C.H. Nelson, A.H. Bouma, et al. $342-373$. doi:10.5724/gcs.00.15.0342

Fedele, J. J., Hoyal, D. C., Barnaal, Z., Tulenko, J., and Awalt, S. (2016). "Bedforms Created by Gravity Flows," in Autogenic Dynamics in Sedimentary Systems. Editors D. Budd, E. Hajek, and S. Purkis (Tulsa: SEPM Special Publication), 106, 95-121.

Fernandez, R. L., Cantelli, A., Pirmez, C., Sequeiros, O., and Parker, G. (2014). Growth Patterns of Subaqueous Depositional Channel Lobe Systems Developed over a Basement with a Downdip Break in Slope: Laboratory Experiments. J. Sediment. Res. 84, 168-182. doi:10.2110/jsr.2014.10

Fildani, A., and Normark, W. R. (2004). Late Quaternary Evolution of Channel and Lobe Complexes of Monterey Fan. Mar. Geology. 206, 199-223. doi:10.1016/j. margeo.2004.03.001

Fildani, A., Hubbard, S. M., Covault, J. A., Maier, K. L., Romans, B. W., Traer, M., et al. (2013). Erosion at Inception of Deep-Sea Channels. Mar. Pet. Geology. 41, 48-61. doi:10.1016/j.marpetgeo.2012.03.006

Fildani, A., Kostic, S., Covault, J. A., Maier, K. L., Caress, D. W., and Paull, C. K. (2021). Exploring a New Breadth of Cyclic Steps on Distal Submarine Fans. Sedimentology 68, 1378-1399. doi:10.1111/sed.12803

Gamberi, F., and Marani, M. (2007). Downstream Evolution of the Stromboli Slope valley (southeastern Tyrrhenian Sea). Mar. Geology. 243, 180-199. doi:10.1016/ j.margeo.2007.05.006

Gamberi, F., and Marani, M. (2011). Geomorphology and Sedimentary Processes of a Modern Confined Braided Submarine Channel belt (Stromboli Slope Valley, Southeastern Tyrrhenian Sea). J. Sediment. Res. 81, 686-701. doi:10. 2110/jsr.2011.56

García, M., and Parker, G. (1989). Experiments on Hydraulic Jumps in Turbidity Currents Near a canyon-fan Transition. Science 245, 393-396. doi:10.1126/ science.245.4916.393

García, M. H. (1989). Depositing and Eroding Sediment Driven Flows: Turbidity Currents. PhD Thesis. Minneapolis, MN: Department of Civil Engineering, University of Minnesota.

García, M. H. (1993). Hydraulic Jumps in Sediment-Driven Bottom Currents. J. Hydraulic Eng. 119, 1094-1117. doi:10.1061/(asce)0733-9429(1993)119:10(1094)

Gardner, J. V., and Dartnell, P. (2002). Multibeam Mapping of the Los Angeles, California Margin. Open-File Report 02-162. United States: U.S. Geological Survey.

Gardner, M. H., Borer, J. M., Melick, J. J., Mavilla, N., Dechesne, M., and Wagerle, R. N. (2003). Stratigraphic Process-Response Model for Submarine Channels and Related Features from Studies of Permian Brushy Canyon Outcrops, West Texas. Mar. Pet. Geology. 20, 757-787. doi:10.1016/j.marpetgeo.2003.07.004

Gardner, J. V., Armstrong, A. A., and Calder, B. R. (2016). Hatteras Transverse Canyon, Hatteras Outer Ridge and Environs of the U.S. Atlantic Margin: a View from Multibeam Bathymetry and Backscatter. Mar. Geology. 371, 18-32. doi:10. 1016/j.margeo.2015.10.015

Gardner, J. V., Peakall, J., Armstrong, A. A., and Calder, B. R. (2020). The Geomorphology of Submarine Channel Systems of the Northern Line
Islands Ridge, Central Equatorial Pacific Ocean. Front. Earth Sci. 8, 87. doi: $10.3389 /$ feart.2020.00087

Gray, T. E., Alexander, J., and Leeder, M. R. (2005). Quantifying Velocity and Turbulence Structure in Depositing Sustained Turbidity Currents across Breaks in Slope. Sedimentology 52, 467-488. doi:10.1111/j.1365-3091.2005.00705.x

Gray, T. E., Alexander, J., and Leeder, M. R. (2006). Longitudinal Flow Evolution and Turbulence Structure of Dynamically Similar, Sustained, Saline Density and Turbidity Currents. J. Geophys. Res. 111, C08015. doi:10.1029/ 2005jc003089

Hamilton, P. B., Strom, K. B., and Hoyal, D. C. J. D. (2015). Hydraulic and Sediment Transport Properties of Autogenic Avulsion Cycles on Submarine Fans with Supercritical Distributaries. J. Geophys. Res. Earth Surf. 120, 1369-1389. doi:10.1002/2014jf003414

Hamilton, P., Gaillot, G., Strom, K., Fedele, J., and Hoyal, D. (2017). Linking Hydraulic Properties in Supercritical Submarine Distributary Channels to Depositional-Lobe Geometry. J. Sediment. Res. 87, 935-950. doi:10.2110/jsr. 2017.53

Hansen, L. A. S., Hodgson, D. M., Pontén, A., Thrana, C., and Obradors Latre, A. (2021a). Mixed Axial and Transverse Deep-water Systems: The Cretaceous Post-Rift Lysing Formation, Offshore Norway. Basin Res. 33, 2229-2251. doi:10.1111/bre.12555

Hansen, L. A. S., Healy, R. S., Gomis-Cartesio, L., Lee, D. R., Hodgson, D. M., Pontén, A., et al. (2021b). The Origin and 3D Architecture of a Km-Scale DeepWater Scour-Fill: Example from the Skoorsteenberg Fm, Karoo Basin, South Africa. Front. Earth Sci. 9, 737932. doi:10.3389/feart.2021.737932

Harris, P. T., Barrie, J. V., Conway, K. W., and Greene, H. G. (2014). Hanging Canyons of Haida Gwaii, British Columbia, Canada: Fault-Control on Submarine Canyon Geomorphology along Active Continental Margins. Deep Sea Res. Part Topical Stud. Oceanography 104, 83-92. doi:10.1016/j. dsr2.2013.06.017

Heijnen, M. S., Clare, M. A., Cartigny, M. J. B., Talling, P. J., Hage, S., Lintern, D. G., et al. (2020). Rapidly-Migrating and Internally-Generated Knickpoints Can Control Submarine Channel Evolution. Nat. Commun. 11, 3129. doi:10.1038/ s41467-020-16861-x

Henstra, G. A., Grundvåg, S.-A., Johannessen, E. P., Kristensen, T. B., Midtkandal, I., Nystuen, J. P., et al. (2016). Depositional Processes and Stratigraphic Architecture within a Coarse-Grained Rift-Margin Turbidite System: The Wollaston Forland Group, East Greenland. Mar. Pet. Geology. 76, 187-209. doi:10.1016/j.marpetgeo.2016.05.018

Hizzett, J. L., Hughes Clarke, J. E., Sumner, E. J., Cartigny, M. J. B., Talling, P. J., and Clare, M. A. (2018). Which Triggers Produce the Most Erosive, Frequent, and Longest Runout Turbidity Currents on Deltas? Geophys. Res. Lett. 45, 855-863. doi:10.1002/2017gl075751

Hodgson, D. M., Kane, I. A., Flint, S. S., Brunt, R. L., and Ortiz-Karpf, A. (2016). Time-Transgressive Confinement on the Slope and the Progradation of BasinFloor Fans: Implications for the Sequence Stratigraphy of Deep-Water Deposits. J. Sediment. Res. 86, 73-86. doi:10.2110/jsr.2016.3

Hofstra, M., Hodgson, D. M., Peakall, J., and Flint, S. S. (2015). Giant Scour-Fills in Ancient Channel-Lobe Transition Zones: Formative Processes and Depositional Architecture. Sediment. Geology. 329, 98-114. doi:10.1016/j. sedgeo.2015.09.004

Hofstra, M., Peakall, J., Hodgson, D. M., and Stevenson, C. J. (2018). Architecture and Morphodynamics of Subcritical Sediment Waves in an Ancient Channel-Lobe Transition Zone. Sedimentology 65, 2339-2367. doi:10.1111/sed.12468

Hughes Clarke, J. E., Brucker, S., Muggah, J., Hamilton, T., Cartwright, D., Church, I., et al. (2012). "Temporal Progression and Spatial Extent of Mass Wasting Events on the Squamish Prodelta Slope," in Landslides and Engineered Slopes: Protecting Society through Improved Understanding. Editors E. Eberhardt, C. Froese, K. Turner, and S. Leroueil (London: Taylor and Francis Group), 1091-1096.

Hughes Clarke, J. E. (2016). First Wide-Angle View of Channelized Turbidity Currents Links Migrating Cyclic Steps to Flow Characteristics. Nat. Commun. 7, 11896. doi:10.1038/ncomms11896

Hughes Clarke, J. E., and Fedele, J. J. (2019). Lobe-channel initiation under unconfined turbidity current flow. American Geophysical Union, Fall Meeting 2019, abstract OS31A-08. Available at: https://ui.adsabs.harvard. edu/abs/2019AGUFMOS31A..08H/abstract 
Ito, M. (2008). Downfan Transformation from Turbidity Currents to Debris Flows at a Channel-To-Lobe Transitional Zone: The Lower Pleistocene Otadai Formation, Boso Peninsula, Japan. J. Sediment. Res. 78, 668-682. doi:10. 2110/jsr.2008.076

Kane, I. A., and Clare, M. A. (2019). Dispersion, Accumulation, and the Ultimate Fate of Microplastics in Deep-marine Environments: A Review and Future Directions. Front. Earth Sci. 7, 80. doi:10.3389/feart.2019.00080

Kenyon, N. H., and Millington, J. (1995). "Contrasting Deep-Sea Depositional Systems in the Bering Sea," in Atlas of Deep-Water Environments: Architectural Styles in Turbidite Systems. Editors K. T. Pickering, R. N. Hiscott, N. H. Kenyon, F. R. Lucchi, and R. D. A. Smith (London: Chapman \& Hall), 196-202. doi:10. 1007/978-94-011-1234-5_28

Kenyon, N. H., Millington, J., Droz, L., and Ivanov, M. K. (1995). "Scour Holes in a Channel-Lobe Transition Zone on the Rhône Cone," in Atlas of Deep-Water Environments: Architectural Styles in Turbidite Systems. Editors K. T. Pickering, R. N. Hiscott, N. H. Kenyon, F. R. Lucchi, and R. D. A. Smith (London: Chapman \& Hall), 212-215. doi:10.1007/978-94-011-1234-5_31

Klaucke, I., Masson, D. G., Kenyon, N. H., and Gardner, J. V. (2004). Sedimentary Processes of the Lower Monterey Fan Channel and Channel-Mouth Lobe. Mar. Geology. 206, 181-198. doi:10.1016/j.margeo.2004.02.006

Komar, P. D. (1971). Hydraulic Jumps in Turbidity Currents. Geol. Soc. America Bull. 82, 1477-1488. doi:10.1130/0016-7606(1971)82[1477:hjitc]2.0.co;2

Konsoer, K., Zinger, J., and Parker, G. (2013). Bankfull Hydraulic Geometry of Submarine Channels Created by Turbidity Currents: Relations between Bankfull Channel Characteristics and Formative Flow Discharge. J. Geophys. Res. Earth Surf. 118, 216-228. doi:10.1029/2012jf002422

Kostic, S., and Parker, G. (2006). The Response of Turbidity Currents to a Canyonfan Transition: Internal Hydraulic Jumps and Depositional Signatures. J. Hydraulic Res. 44, 631-653. doi:10.1080/00221686.2006.9521713

Kostic, S., and Parker, G. (2007). Conditions under Which a Supercritical Turbidity Current Traverses an Abrupt Transition to Vanishing Bed Slope without a Hydraulic Jump. J. Fluid Mech. 586, 119-145. doi:10.1017/s0022112007006738

Lang, J., Fedele, J. J., and Hoyal, D. C. J. D. (2021). Three-Dimensional Submerged Wall Jets and Their Transition to Density Flows: Morphodynamics and Implications for the Depositional Record. Sedimentology 68, 1297-1327. doi:10.1111/sed.12860

Launder, B. E., and Rodi, W. (1983). The Turbulent Wall Jet Measurements and Modeling. Annu. Rev. Fluid Mech. 15, 429-459. doi:10.1146/annurev.fl.15. 010183.002241

Lee, S. E., Talling, P. J., Ernst, G. G. J., and Hogg, A. J. (2002). Occurrence and Origin of Submarine Plunge Pools at the Base of the US continental Slope. Mar. Geology. 185, 363-377. doi:10.1016/S0025-3227(01)00298-5

Lee, S. E., Amy, L. A., and Talling, P. J. (2004). "The Character and Origin of Thick Base-Of-Slope sandstone Units of the Peirra Cava Outlier, SE France," in DeepWater Sedimentation in the Alpine Basin of SE France: New Perspectives on the Gres d'Annot and Related Systems. Editors P. Joseph and S. A. Lomas (Bath, UK: Geological Society, London, Special Publications), 221, 331-347. doi:10.1144/ gsl.sp.2004.221.01.18

Lewis, K. B. (1994). The 1500-Km-Long Hikurangi Channel: Trench-Axis Channel that Escapes its Trench, Crosses a Plateau, and Feeds a Fan Drift. Geo-Marine Lett. 14, 19-28. doi:10.1007/bf01204467

Lien, T., Walker, R. G., and Martinsen, O. J. (2003). Turbidites in the Upper Carboniferous Ross Formation, Western Ireland: Reconstruction of a Channel and Spillover System. Sedimentology 50, 113-148. doi:10.1046/j.1365-3091.2003. 00541.x

Macdonald, H. A., Wynn, R. B., Huvenne, V. A. I., Peakall, J., Masson, D. G., Weaver, P. P. E., et al. (2011a). New Insights into the Morphology, Fill, and Remarkable Longevity ( $>0.2$ m.y.) of Modern Deep-Water Erosional Scours along the Northeast Atlantic Margin. Geosphere 7, 845-867. doi:10.1130/GES00611.1

Macdonald, H. A., Peakall, J., Wignall, P. B., and Best, J. (2011b). Sedimentation in Deep-Sea Lobe-Elements: Implications for the Origin of Thickening-Upward Sequences. J. Geol. Soc. 168, 319-332. doi:10.1144/0016-76492010-036

Maier, K. L., Roland, E. C., Walton, M. A. L., Conrad, J. E., Brothers, D. S., Dartnell, P., et al. (2018). The Tectonically Controlled San Gabriel Channel-Lobe Transition Zone, Catalina Basin, Southern California Borderland. J. Sed. Res. 88, 942-959. doi:10.2110/jsr.2018.50

Maier, K. L., Paull, C. K., Caress, D. W., Anderson, K., Nieminski, N. M., Lundsten, E., et al. (2020). Submarine-Fan Development Revealed by Integrated High-
Resolution Datasets from La Jolla Fan, Offshore California, U.S.A. J. Sed. Res. 90, 468-479. doi:10.2110/jsr.2020.22

Mansor, H. E., and Amir Hassan, M. H. (2021). Facies and Bed Type Characteristics of Channel-Lobe Transition Deposits from the OligoceneMiocene Tajau Sandstone Member, Kudat Formation, Sabah, Malaysia. Geol. J. 56, 5642-5672. doi:10.1002/gj.4263

Mayer, L. A., and Gardner, J. V. (2016). "Cascades and Plunge Pools on the continental Slope of the Gulf of Alaska," in Atlas of Submarine Glacial Landforms: Modern, Quaternary and Ancient. Editors J. A. Dowdeswell, M. Canals, M. Jakobsson, B. J. Todd, E. K. Dowdeswell, and K. A. Hogan (Bath, UK: Geological Society of London, Memoir), 46, 389-390. doi:10.1144/M46.20

Morris, S. A., Alexander, J., Kenyon, N. H., and Limonov, A. F. (1998). Turbidites Around an Active Fault Scarp on the Lower Valencia Fan, Northwest Mediterranean. Geo-Marine Lett. 18, 165-171. doi:10.1007/s003670050064

Mulder, T., Ducassou, E., Gillet, H., Hanquiez, V., Tournadour, E., Combes, J., et al. (2012). Canyon Morphology on a Modern Carbonate Slope of the Bahamas: Evidence of Regional Tectonic Tilting. Geology 40, 771-774. doi:10.1130/ G33327.1

Mulder, T., Gillet, H., Hanquiez, V., Reijmer, J. J. G., Droxler, A. W., Recouvreur, A., et al. (2019). Into the Deep: A Coarse-Grained Carbonate Turbidite Valley and Canyon in Ultra-Deep Carbonate Setting. Mar. Geology. 407, 316-333. doi:10.1016/j.margeo.2018.11.003

Mutti, E., and Normark, W. R. (1987). "Comparing Examples of Modern and Ancient Turbidite Systems: Problems and Concepts," in Marine Clastic Sedimentology: Concepts and Case Studies. Editors J. K. Leggett and G. G. Zuffa (London: Graham and Trotman), 1-38. doi:10.1007/978-94-009-3241-8_1

Mutti, E., and Normark, W. R. (1991). "An Integrated Approach to the Study of Turbidite Systems," in Seismic Facies and Sedimentary Processes of Submarine Fans and Turbidite Systems. Editors P. Weimer and M. H. Link (New York: Springer-Verlag), 75-106. doi:10.1007/978-1-4684-8276-8_4

Navarro, L., and Arnott, R. W. C. (2020). Stratigraphic Record in the Transition from Basin Floor to Continental Slope Sedimentation in the Ancient PassiveMargin Windermere Turbidite System. Sedimentology 67, 1710-1749. doi:10. $1111 /$ sed.12676

Nelson, C. H., Goldfinger, C., Johnson, J. E., and Dunhill, G. (2000). "Variation of Modem Turbidite Systems Along the Subduction Zone Margin of Cascadia Basin and Implications for Turbidite Reservoir Beds," in Proceedings Deep Reservoirs of the World, SEPM, Gulf Coast Section, 20th Annual Bob F. Perkins Research Conference, Houston, Texas, December 3-6, 2000. Editors P. Weimer, R. M. Slatt, J. Coleman, N.C. Rosen, C. H. Nelson, A. H. Bouma, et al. 714-738. doi:10.5724/gcs.00.15.0714

Normark, W. R., and Piper, D. J. W. (1991). "Initiation Processes and Flow Evolution of Turbidity Currents: Implications for the Depositional Record," in From Shoreline to Abyss. Editor R. H. Osborne (Tulsa: SEPM. Spec. Publ.), 46, 207-230. doi:10.2110/pec.91.09.0207

Normark, W. R., Piper, D. J. W., and Hess, G. R. (1979). Distributary Channels, Sand Lobes, and Mesotopography of Navy Submarine Fan, California Borderland, with Applications to Ancient Fan Sediments. Sedimentology 26, 749-774. doi:10.1111/j.1365-3091.1979.tb00971.x

Normark, W. R., Piper, D. J. W., Romans, B. W., Covault, J. A., Dartnell, P., and Sliter, R. W. (2009). "Submarine canyon and Fan Systems of the California Continental Borderland," in Earth Science in the Urban Ocean: The Southern California Continental Borderland. Editors H. J. Lee and W. R. Normark (Boulder: Geological Society of America Special Paper), 454, 141-168. doi:10.1130/2009.2454(2.7)

Normark, W. R. (1970). Growth Patterns of Deep-Sea Fans. Am. Assoc. Petrol. Geol. Bull. 54, 2170-2195. doi:10.1306/5d25cc79-16c1-11d7-8645000102c1865d

Normark, W. R. (1985). "Local Morphologic Controls and Effects of basin Geometry on Flow Processes in Deep marine Basins," in Provenance of Arenites. Editor G. G. Zuffa (Dordrecht: NATO ASI Series. Series C: Mathematical and Physical Sciences, Reidel), 148, 47-63. doi:10.1007/97894-017-2809-6_3

Ó Cofaigh, C., Dowdeswell, J. A., and Kenyon, N. H. (2006). Geophysical Investigations of a High-Latitude Submarine Channel System and Associated Channel-Mouth Lobe in the Lofoten Basin, Polar North Atlantic. Mar. Geology. 226, 41-50. doi:10.1016/j.margeo.2005.09.014

Patton, J. R., Goldfinger, C., Morey, A. E., Romsos, C., Black, B., Djadjadihardja, Y., et al. (2013). Seismoturbidite Record as Preserved at Core Sites at the Cascadia 
and Sumatra-Andaman Subduction Zones. Nat. Hazards Earth Syst. Sci. 13, 833-867. doi:10.5194/nhess-13-833-2013

Paull, C. K., Caress, D. W., Ussler, W., III, Lundsten, E., and Meiner-Johnson, M. (2011). High-Resolution Bathymetry of the Axial Channels within Monterey and Soquel Submarine Canyons, Offshore Central California. Geosphere 7, 1077-1101. doi:10.1130/GES00636.1

Paull, C. K., Caress, D. W., Lundsten, E., Gwiazda, R., Anderson, K., McGann, M., et al. (2013). Anatomy of the La Jolla Submarine Canyon System; Offshore Southern California. Mar. Geology. 335, 16-34. doi:10.1016/j.margeo.2012.10.003

Peakall, J., and Sumner, E. J. (2015). Submarine Channel Flow Processes and Deposits: A Process-Product Perspective. Geomorphology 244, 95-120. doi:10. 1016/j.geomorph.2015.03.005

Pemberton, E. A. L., Hubbard, S. M., Fildani, A., Romans, B., and Stright, L. (2016). The Stratigraphic Expression of Decreasing Confinement along a Deep-Water Sediment Routing System: Outcrop Example from Southern Chile. Geosphere 12, 114-134. doi:10.1130/ges01233.1

Picot, M., Droz, L., Marsset, T., Dennielou, B., and Bez, M. (2016). Controls on Turbidite Sedimentation: Insights from a Quantitative Approach of Submarine Channel and Lobe Architecture (Late Quaternary Congo Fan). Mar. Pet. Geology. 72, 423-446. doi:10.1016/j.marpetgeo.2016.02.004

Piper, D. J. W. (1970). Transport and Deposition of Holocene Sediment on La Jolla Deep Sea Fan, California. Mar. Geology. 8, 211-227. doi:10.1016/0025-3227(70) 90044-7

Pirmez, C., and Imran, J. (2003). Reconstruction of Turbidity Currents in Amazon Channel. Mar. Pet. Geology. 20, 823-849. doi:10.1016/j.marpetgeo.2003.03.005

Pohl, F., Eggenhuisen, J. T., Tilston, M., and Cartigny, M. J. B. (2019). New Flow Relaxation Mechanism Explains Scour fields at the End of Submarine Channels. Nat. Commun. 10, 4425. doi:10.1038/s41467-019-12389-x

Pohl, F., Eggenhuisen, J. T., Cartigny, M. J. B., Tilston, M. C., de Leeuw, J., and Hermidas, N. (2020). The Influence of a Slope Break on Turbidite Deposits: An Experimental Investigation. Mar. Geology. 424, 106160. doi:10.1016/j.margeo.2020.106160

Posamentier, H. W., and Kolla, V. (2003). Seismic Geomorphology and Stratigraphy of Depositional Elements in Deep-Water Settings. J. Sediment. Res. 73, 367-388. doi:10.1306/111302730367

Postma, G., Hoyal, D. C., Abreu, V., Cartigny, M. J. B., Demko, T., Fedele, J. J., et al. (2016). "Morphodynamics of Supercritical Turbidity Currents in the ChannelLobe Transition Zone," in Submarine Mass Movements and their Consequences. Editors G. Lamarche, J. Mountjoy, S. Bull, T. Hubble, S. Krastel, E. Lane, et al. Cham: Springer. 41, 469-478. doi:10.1007/978-3319-20979-1_47

Postma, G., Lang, J., Hoyal, D. C., Fedele, J. J., Demko, T., Abreu, V., et al. (2021). Reconstruction of Bedform Dynamics Controlled by Supercritical Flow in the Channel-Lobe Transition Zone of a Deep-Water Delta (Sant Llorenç del Munt, North-East Spain, Eocene). Sedimentology 68, 1674-1697. doi:10.1111/sed.12735

Pyles, D. R., Strachan, L. J., and Jennette, D. C. (2014). Lateral Juxtapositions of Channel and Lobe Elements in Distributive Submarine Fans: ThreeDimensional Outcrop Study of the Ross Sandstone and Geometric Model. Geosphere 10, 1104-1122. doi:10.1130/ges01042.1

Pyles, D. R. (2008). Multiscale Stratigraphic Analysis of a Structurally Confined Submarine Fan: Carboniferous Ross Sandstone, Ireland. Bulletin 92, 557-587. doi:10.1306/01110807042

Recouvreur, A., Fabregas, N., Mulder, T., Hanquiez, V., Fauquembergue, K., Tournadour, E., et al. (2021). Geomorphology of a Modern Carbonate Slope System and Associated Sedimentary Processes: Example of the Giant Great Abaco Canyon, Bahamas. Sedimentology 68, 266-293. doi:10.1111/sed.12777

Reijmer, J. J. G., Mulder, T., and Borgomano, J. (2015). Carbonate Slopes and Gravity Deposits. Sediment. Geology. 317, 1-8. doi:10.1016/j.sedgeo.2014.12.001

Salinas, J., Balachandar, S., Shringarpure, M., Fedele, J., Hoyal, D., and Cantero, M. (2020). Soft Transition between Subcritical and Supercritical Currents through Intermittent Cascading Interfacial Instabilities. Proc. Natl. Acad. Sci. USA 117, 18278-18284. doi:10.1073/pnas.2008959117

Schnyder, J. S. D., Eberli, G. P., Betzler, C., Wunsch, M., Lindhorst, S., Schiebel, L., et al. (2018). Morphometric Analysis of Plunge Pools and Sediment Wave fields along Western Great Bahama Bank. Mar. Geology. 397, 15-28. doi:10.1016/j. margeo.2017.11.020

Shaw, J., Puig, P., and Han, G. (2013). Megaflutes in a continental Shelf Setting, Placentia Bay, Newfoundland. Geomorphology 189, 12-25. doi:10.1016/j. geomorph.2013.01.010
Shepard, F. P. (1951). "Transportation of Sand into Deep Water," in Turbidity Currents and the Transportation of Coarse Sediment to Deep Water. Editor J. L. Hough (Tulsa: SEPM Sp. Pub.), 2, 53-65. doi:10.2110/pec.51.02.0053

Simmons, S. M., Azpiroz-Zabala, M., Cartigny, M. J. B., Clare, M. A., Cooper, C., Parsons, D. R., et al. (2020). Novel Acoustic Method Provides First Detailed Measurements of Sediment Concentration Structure within Submarine Turbidity Current. J. Geophys. Res. Oceans 125, e2019JC015904. doi:10. 1029/2019jc015904

Spychala, Y. T., Eggenhuisen, J. T., Tilston, M., and Pohl, F. (2020). The Influence of basin Setting and Turbidity Current Properties on the Dimensions of Submarine Lobe Elements. Sedimentology 67, 3471-3491. doi:10.1111/sed.12751

Stevenson, C. J., Jackson, C. A.-L., Hodgson, D. M., Hubbard, S. M., and Eggenhuisen, J. T. (2015). Deep-Water Sediment Bypass. J. Sediment. Res. 85, 1058-1081. doi:10.2110/jsr.2015.63

Stow, D., and Smillie, Z. (2020). Distinguishing between Deep-Water Sediment Facies: Turbidites, Contourites and Hemipelagites. Geosciences 10, 68. doi:10. 3390/geosciences 10020068

Straub, K. M., and Pyles, D. R. (2012). Quantifying the Hierarchical Organization of Compensation in Submarine Fans Using Surface Statistics. J. Sediment. Res. 82, 889-898. doi:10.2110/jsr.2012.73

Sumner, E. J., Peakall, J., Parsons, D. R., Wynn, R. B., Darby, S. E., Dorrell, R. M., et al. (2013). First Direct Measurements of Hydraulic Jumps in an Active Submarine Density Current. Geophys. Res. Lett. 40, 5904-5908. doi:10.1002/ $2013 \mathrm{gl} 057862$

Van der Merwe, W. C., Hodgson, D. M., Brunt, R. L., and Flint, S. S. (2014). Depositional Architecture of Sand-Attached and Sand-Detached Channel-Lobe Transition Zones on an Exhumed Stepped Slope Mapped over a $2500 \mathrm{Km} 2$ Area. Geosphere 10, 1076-1093. doi:10.1130/ges01035.1

Vendettuoli, D., Clare, M. A., Hughes Clarke, J. E., Vellinga, A., Hizzet, J., Hage, S., et al. (2019). Daily Bathymetric Surveys Document How Stratigraphy Is Built and its Extreme Incompleteness in Submarine Channels. Earth Planet. Sci. Lett. 515, 231-247. doi:10.1016/j.epsl.2019.03.033

Wang, W., Wang, D., Sun, J., Shao, D., Lu, Y., Chen, Y., et al. (2020). Evolution of deepwater Turbidite Bedforms in the Huaguang Channel-Lobe Transition Zone Revealed by 3D Seismic Data in the Qiongdongnan Basin, South China Sea. Geomorphology 370, 107412. doi:10.1016/j.geomorph.2020.107412

Wells, M. G., and Dorrell, R. M. (2021). Turbulence Processes within Turbidity Currents. Annu. Rev. Fluid Mech. 53, 59-83. doi:10.1146/annurev-fluid010719-060309

Wynn, R. B., Kenyon, N. H., Masson, D. G., Stow, D. A. V., and Weaver, P. P. E. (2002a). Characterization and Recognition of Deep-Water Channel-Lobe Transition Zones. Am. Assoc. Petrol. Geol. Bull. 86, 1441-1462. doi:10.1306/ 61eedcc4-173e-11d7-8645000102c1865d

Wynn, R. B., Piper, D. J. W., and Gee, M. J. R. (2002b). Generation and Migration of Coarse-Grained Sediment Waves in Turbidity Current Channels and Channel-Lobe Transition Zones. Mar. Geology. 192, 59-78. doi:10.1016/ s0025-3227(02)00549-2

Yu, G., and Tan, S.-K. (2006). Errors in the Bed Shear Stress as Estimated from Vertical Velocity Profile. J. Irrig. Drain Eng. 132, 490-497. doi:10.1061/(asce) 0733-9437(2006)132:5(490)

Conflict of Interest: The authors declare that the research was conducted in the absence of any commercial or financial relationships that could be construed as a potential conflict of interest.

Publisher's Note: All claims expressed in this article are solely those of the authors and do not necessarily represent those of their affiliated organizations, or those of the publisher, the editors, and the reviewers. Any product that may be evaluated in this article, or claim that may be made by its manufacturer, is not guaranteed or endorsed by the publisher.

Copyright (๑) 2022 Hodgson, Peakall and Maier. This is an open-access article distributed under the terms of the Creative Commons Attribution License (CC BY). The use, distribution or reproduction in other forums is permitted, provided the original author(s) and the copyright owner(s) are credited and that the original publication in this journal is cited, in accordance with accepted academic practice. No use, distribution or reproduction is permitted which does not comply with these terms. 